\title{
Thermobarometric Constraints on Mid-Cretaceous to Late Cretaceous Metamorphic Events in the Western Metamorphic Belt of the Coast Mountains Complex near Petersburg, Southeastern Alaska
}

\author{
By Glen R. Himmelberg and David A. Brew
}

\section{Abstract}

The western metamorphic belt is part of the Coast Mountains Complex of southeastern Alaska and western Canada. This complex formed as a result of mid-Cretaceous through middle Eocene crustal shortening between the previously amalgamated Wrangellia and Alexander terranes (Insular superterrane) and previously accreted terranes of the North American continental margin (Intermontane superterrane). The western metamorphic belt, which ranges from a few kilometers to several tens of kilometers in width, records a complex sequence of contact-metamorphic and regional metamorphic events, the most significant of which are designated $\mathrm{M}_{1}^{\mathrm{R}}, \mathrm{M}_{2}^{\mathrm{C}-\mathrm{R}}$, and $\mathrm{M}_{3}^{\mathrm{R}}$. The $\mathrm{M}_{1}^{\mathrm{R}}$ regional metamorphic event ranged in grade from subgreenschist to greenschist facies and was overprinted by the $\mathrm{M}_{2}^{\mathrm{C}-\mathrm{R}}$ and $\mathrm{M}_{3}^{\mathrm{R}}$ metamorphic events. The $\mathrm{M}_{2}^{\mathrm{C}-\mathrm{R}}$ metamorphic event is recorded in discrete contact-metamorphic aureoles and regional metamorphic-mineral assemblages related to tonalite-granodiorite plutons of the Admiralty-Revillagigedo plutonic belt. The $\mathrm{M}_{3}^{\mathrm{R}}$ metamorphic belt, which is adjacent to the $\mathrm{M}_{2}^{\mathrm{C}-\mathrm{R}}$ belt, is characterized by regional Barrovian isograds of garnet, staurolite, kyanite, and sillimanite. Using the THERMOCALC program, pressure-temperature $(\mathrm{P}-\mathrm{T})$ conditions for the $\mathrm{M}_{2}^{\mathrm{C}-\mathrm{R}}$ metamorphic event are estimated to be in the ranges 5.3-7.5 kbars and $525-640^{\circ} \mathrm{C}$ and for the $\mathrm{M}_{3}^{\mathrm{R}}$ metamorphic event in the ranges $9.4-12.6$ kbars and $730-895^{\circ} \mathrm{C}$. The $\mathrm{M}_{2}^{\mathrm{C}-\mathrm{R}}$ metamorphic event occurred at approximately $90 \mathrm{Ma}$, but the timing of the $\mathrm{M}_{3}^{\mathrm{R}}$ metamorphic event is poorly documented and uncertain. On the basis of an ${ }^{40} \mathrm{Ar} /{ }^{39} \mathrm{Ar}$ age on actinolitic amphibole and a Sm-Nd age on garnet core, the timing of metamorphism might be constrained between $90 \pm 1$ and $80 \pm 9 \mathrm{Ma}$, although the Sm-Nd age of $80 \pm 9$ m.y. possibly reflects postpeak growth. Thermobarometric data suggest that the two events occurred at different crustal levels and followed different $\mathrm{P}-\mathrm{T}$ paths. No evidence exists that $\mathrm{M}_{2}^{\mathrm{C}-\mathrm{R}}$ metamorphic-mineral assemblages were overprinted by the $\mathrm{M}_{3}^{\mathrm{R}}$ metamorphic event, as proposed by some workers. Juxtaposition of the two belts of rocks probably occurred along the Coast shear zone during uplift and exhumation of the Coast Mountains.

\section{Introduction}

The plutonic and metamorphic rocks of southeastern Alaska and western Canada constitute part of the Coast Mountains Complex (Brew and others, 1995; referred to as the Coast Plutonic Complex by Stowell and McClelland, 2000). This complex formed as a result of mid-Cretaceous through middle Eocene crustal shortening between the previously amalgamated Wrangellia and Alexander terranes (Insular superterrane) and previously accreted terranes of the North American continental margin (Intermontane superterrane) (Monger and others, 1982). From west to east, the Coast Mountains Complex consists of the western metamorphic belt, the central pluton gneiss belt, and the eastern metamorphic belt (Crawford and others, 1987; Brew and others, 1989, 1995). The central pluton gneiss belt was named the "Coast Range batholith" by Buddington and Chapin (1929), and that designation, or "Coast Mountains batholith," is still used by some workers.

The magmatic, metamorphic, and deformational history of mid-Cretaceous through middle Eocene crustal contraction is partly recorded in the western metamorphic belt (figs. 1,2). The sequence of plutonic, metamorphic, and deformational events therein is recognized by most workers in the Coast Mountains, and polymetamorphic overprinting of the $\mathrm{M}_{1}^{\mathrm{R}}$ by the $\mathrm{M}_{2}^{\mathrm{C}-\mathrm{R}}$ metamorphic event has been documented (Brew and others, 1989; Stowell and Crawford, 2000). However, the temporal and spatial relations of the $\mathrm{M}_{2}^{\mathrm{C}-\mathrm{R}}$ and $\mathrm{M}_{3}^{\mathrm{R}}$ metamorphic events are poorly understood. Most workers (Douglass and Brew, 1985; Brew and others, 1989; Himmelberg and others, 1991; Stowell and Crawford, 2000; Himmelberg and others, 2004) have assumed that the east side of the belt of rocks affected by the $\mathrm{M}_{2}^{\mathrm{C}-\mathrm{R}}$ metamorphic event was overprinted by the $\mathrm{M}_{3}^{\mathrm{R}}$ (Barrovian) metamorphic event, but data have not been presented to document polymetamorphism.

In this chapter, we integrate mineral associations and new thermobarometric data with existing geologic mapping and geochronology to evaluate and compare the pressure-temperature (P-T) paths of the $\mathrm{M}_{2}^{\mathrm{C}-\mathrm{R}}$ and $\mathrm{M}_{3}^{\mathrm{R}}$ metamorphic events and elucidate their implications for the tectonic evolution of the study area (fig. 2). Most of the data are from the Petersburg, 
Alaska, 1:250,000-scale quadrangle, where numerous $\mathrm{M}_{2}^{\mathrm{C}-\mathrm{R}}$ contact-metamorphic aureoles occur adjacent to, and in some interpretations spatially overlap with, an extensive belt of $\mathrm{M}_{3}^{\mathrm{R}}$ (Barrovian) metamorphic rocks.

\section{Geologic Setting}

The western metamorphic belt (fig. 1) consists of rocks of the Yukon-Tanana and Taku terranes (Gehrels and others, 1990) along its east side, and rocks of the Gravina belt (Berg and others, 1972; Cohen and Lundberg, 1993) along its west side. The Yukon-Tanana terrane, which was originally called the Tracy Arm terrane by Berg and others (1978), is a Proterozoic through Paleozoic continental-margin assemblage (Gehrels and others, 1990). The Taku terrane is a highly faulted Paleozoic through Mesozoic sequence of arc-related rocks (Rubin and Saleeby, 1991), which Brew (2001) interpreted as a structural zone and not as a terrane. The Gravina belt is a Late Jurassic through Early Cretaceous sequence of arc-derived volcanic and sedimentary rocks that was deposited on the eastern margin of the Alexander terrane and on the Taku terrane (Berg and others, 1972; Rubin and Saleeby, 1991; Cohen and Lundberg, 1993).

During mid-Cretaceous time, a major contractional episode occurred between the previously amalgamated Alexander and Wrangellia terranes and previously accreted terranes to the east (Monger and others, 1982; Gehrels and others, 1990; Rubin and others, 1990; Brew and others, 1992; McClelland and Mattinson, 2000). Although closure of the Gravina Basin, which lay between the Alexander terrane and previously accreted parts of North America, also occurred during that time (Berg and others, 1972; McClelland and Gehrels, 1990; Haeussler, 1992), the initial collision between the Alexander terrane and the continental margin occurred earlier (McClelland and Gehrels, 1990; Gehrels, 2001). In the early part of the contractional episode, deformation centered in the western metamorphic belt; and at the latitude of British Columbia, it continued within the central pluton gneiss belt until middle Eocene time (for example, McClelland and Mattinson, 2000; Stowell and Crawford, 2000). In southeastern Alaska, however, deformation had ceased by then, as evidenced by abundant undeformed Eocene plutons (Brew, 1994).

The western metamorphic belt, which ranges from a few kilometers to several tens of kilometers in width, records a complex sequence of contact-metamorphic and regional metamorphic events (Brew and others, 1989; Stowell and Crawford, 2000). In general, the Late Cretaceous through early Tertiary Coast shear zone, a steep, crustal-scale, hightemperature shear zone, separates the western metamorphic belt from the Coast Mountains batholith (McClelland and others, 1992; Brew and Ford, 1998; Klepeis and others, 1998; Brew, 2001), although in some places the Coast shear zone lies entirely within the western metamorphic belt and in other places within plutons of the great tonalite sill on the west side of the Coast Mountain batholith (figs. 1, 2). Brew and Ford (1998) and Brew (2001) considered this zone to be a com- posite of several structural elements. Metamorphic studies of the western metamorphic belt have been concentrated near Juneau, Alaska (Ford and Brew, 1973, 1977; Himmelberg and others, 1991, 1994a, b, 1995), Petersburg, Alaska (Douglas and Brew, 1985; McClelland and others, 1991; Stowell and others, 2001; Stowell and Tinkham, 2003; Himmelberg and others, 2004), and southern southeastern Alaska and northern British Columbia (Crawford and Hollister, 1982; Crawford and others, 1987; Cook and others, 1991; Cook and Crawford, 1994; Klepeis and others, 1998). In addition, Stowell (1989) reported on the thermobarometry of schists in the Holkham Bay area of Alaska, $80 \mathrm{~km}$ south of Juneau. Tectonic studies of the western metamorphic belt were reported by Stowell and Hooper (1990), McClelland and others (1992), Gehrels and others (1992), Haeussler (1992), Rubin and Saleeby (1992), Ingram and Hutton (1994), and Crawford and others (2000).

Regional metamorphism before 110-100 Ma in the western metamorphic belt was dynamothermal and designated $M_{1}$ by Brew and others (1989) and $\mathrm{M}_{1}^{\mathrm{R}}$ by Stowell and Crawford (2000). Karl and others (1999) suggested that more than one metamorphic event occurred before 110-100 Ma, but such events have not been documented. Thus, we use $\mathrm{M}_{1}^{\mathrm{R}}$ to indicate all regional metamorphism earlier than 110-100 Ma. The $\mathrm{M}_{1}^{\mathrm{R}}$ metamorphic rocks range from subgreenschist to greenschist facies in grade (Brew and others, 1984, 1989; Himmelberg and others, 1995). Evidence for the $\mathrm{M}_{1}^{\mathrm{R}}$ metamorphic event is best preserved along the western margin of the belt, where this event has not been overprinted by later, higher-grade metamorphic events (fig. 2). The other regionally significant metamorphic events in the western metamorphic belt were (1) contact metamorphism by mid-Cretaceous (101-83 Ma) tonalite-granodiorite plutons of the Admiralty-Revillagigedo plutonic belt $\left(\mathrm{M}_{4}\right.$ and $\mathrm{M}_{4}^{\prime}$ in the notation of Brew and others, $1989 ; \mathrm{M}_{2}^{\mathrm{C}-\mathrm{R}}$ in the notation of Stowell and Crawford, 2000); (2) regional high-pressure Barrovian metamorphism $\left(\mathrm{M}_{5}\right.$ in the notation of Brew and others, 1989; $\mathrm{M}_{3}^{\mathrm{R}}$ in the notation of Stowell and Crawford, 2000), and (3) metamorphism superimposed on the east side of the Barrovian metamorphic belt by plutons of the great tonalite sill $\left(\mathrm{M}_{5}\right.$ in the notation of Brew and others, $1989 ; \mathrm{M}_{4}^{\mathrm{C}-\mathrm{R}}$ in the notation of Stowell and Crawford, 2000). Henceforth we use the metamorphic-event notation of Stowell and Crawford (2000) without reference to the earlier notation of Brew and others (1989).

\section{Characteristic Mineral Associations and Chemistry}

The $\mathrm{M}_{2}^{\mathrm{C}-\mathrm{R}}$ metamorphic event is recorded in contact-metamorphic aureoles formed around tonalite-granodiorite intrusions of the Admiralty-Revillagigedo plutonic belt that were emplaced in the western metamorphic belt about 101-83 Ma (figs. 1, 2; Douglas and Brew, 1985; Brew and others, 1989; Douglass and others, 1989; Gehrels and others, 1992; McClelland and others, 1992; McClelland and Mattinson, 2000; 


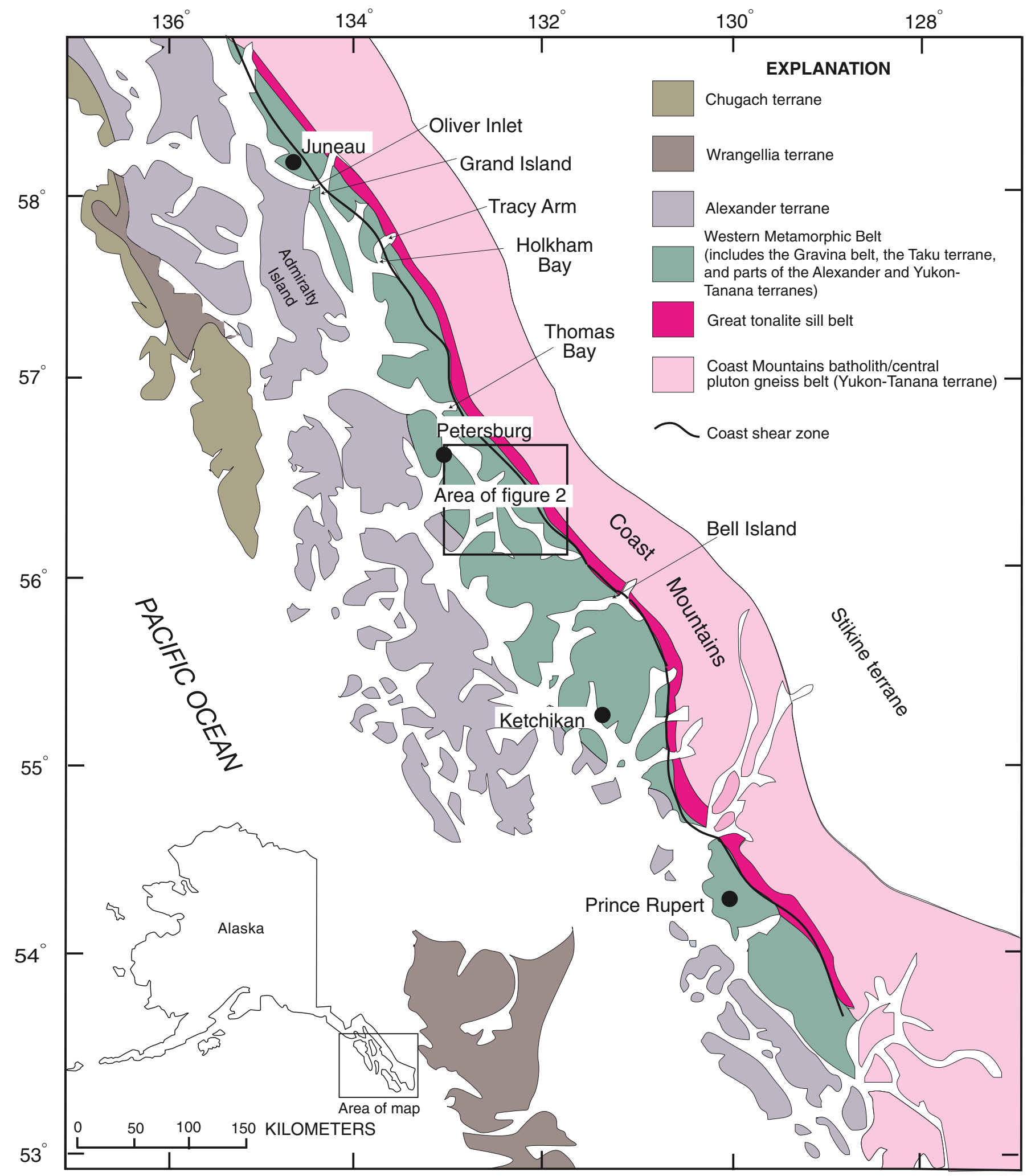

Figure 1. Sketch tectonostratigraphic map of southeastern Alaska, showing locations of the Coast Mountains Complex (Brew and others, 1995), the Coast shear zone (McClelland and others, 1992; Brew and Ford, 1998; Klepeis and others, 1998; Brew, 2001), the western metamorphic belt (Brew and others, 1989; Stowell and Crawford, 2000), the great tonalite sill (Brew, 1994), and the Chugach, Wrangellia, and Alexander terranes (Gehrels and others, 1990; Rubin and Saleeby, 1991). 
Table 1. Mineral assemblages in samples of metamorphic rocks selected for thermobarometric calculations.

[Metamorphic minerals: and, andalusite; bt, biotite; cpx, clinopyroxene; grt, garnet; hbl, hornblende; ky, kyanite; ms, muscovite; pl, plagioclase; qtz, quartz; sil, sillimanite; st, staurolite. x, present and stable; [x], relict and metastable]

\begin{tabular}{|c|c|c|c|c|c|c|c|c|c|c|c|c|}
\hline \multirow{2}{*}{ Sample } & \multirow{2}{*}{$\begin{array}{c}\text { Metamorphic } \\
\text { event }\end{array}$} & \multicolumn{11}{|c|}{ Metamorphic minerals } \\
\hline & & $\mathrm{ms}$ & bt & grt & st & and & sil & ky & $\mathrm{hbl}$ & $\operatorname{cpx}$ & qtz & $\mathrm{pl}$ \\
\hline $20 \mathrm{D}$ & $\mathrm{M}_{2}^{\mathrm{R}}$ & $\mathrm{x}$ & $\mathrm{x}$ & $\mathrm{x}$ & -- & -- & -- & -- & -- & -- & $\mathrm{x}$ & $\mathrm{x}$ \\
\hline $21 \mathrm{~B}$ & $\mathrm{M}_{2}^{\mathrm{R}}$ & $\mathrm{x}$ & $\mathrm{x}$ & $\mathrm{x}$ & $\mathrm{x}$ & -- & -- & -- & -- & -- & $\mathrm{x}$ & $\mathrm{x}$ \\
\hline $21 \mathrm{C}$ & $\mathrm{M}_{2}^{\mathrm{R}}$ & $\mathrm{x}$ & $\mathrm{x}$ & $\mathrm{x}$ & $\mathrm{x}$ & -- & -- & $\mathrm{x}$ & -- & -- & $\mathrm{x}$ & $\mathrm{x}$ \\
\hline $21 \mathrm{D}$ & $\mathrm{M}_{2}^{\mathrm{R}}$ & $\mathrm{x}$ & $\mathrm{x}$ & $\mathrm{x}$ & $\mathrm{x}$ & -- & -- & $\mathrm{x}$ & -- & -- & $\mathrm{x}$ & $\mathrm{x}$ \\
\hline $94 \mathrm{~A}$ & $\mathrm{M}_{2}^{\mathrm{R}}$ & $\mathrm{x}$ & $\mathrm{x}$ & $\mathrm{x}$ & $\mathrm{x}$ & -- & -- & {$[\mathrm{x}]$} & -- & -- & $\mathrm{x}$ & $\mathrm{x}$ \\
\hline $95 \mathrm{~A}$ & $\mathrm{M}_{2}^{\mathrm{R}}$ & $\mathrm{x}$ & $\mathrm{x}$ & $\mathrm{x}$ & -- & -- & -- & {$[\mathrm{x}]$} & -- & -- & $\mathrm{x}$ & $\mathrm{x}$ \\
\hline $91 \mathrm{~A}$ & $\mathrm{M}_{3}^{\mathrm{R}}$ & -- & -- & $\mathrm{x}$ & -- & -- & -- & -- & $x$ & $\mathrm{x}$ & $\mathrm{x}$ & $\mathrm{x}$ \\
\hline $112 \mathrm{~A}$ & $\mathrm{M}_{3}^{\mathrm{R}}$ & -- & -- & $\mathrm{x}$ & -- & -- & -- & -- & $\mathrm{x}$ & -- & $\mathrm{x}$ & $\mathrm{x}$ \\
\hline $192 \mathrm{~A}$ & $\mathrm{M}_{3}^{\mathrm{R}}$ & -- & $\mathrm{x}$ & $\mathrm{x}$ & -- & -- & -- & -- & $\mathrm{x}$ & -- & $\mathrm{x}$ & $\mathrm{x}$ \\
\hline $202 \mathrm{~A}$ & $\mathrm{M}_{3}^{\mathrm{R}}$ & -- & $\mathrm{x}$ & $\mathrm{x}$ & -- & -- & -- & -- & $\mathrm{x}$ & -- & $\mathrm{x}$ & $\mathrm{x}$ \\
\hline 190D & $\mathrm{M}_{3}^{\mathrm{R}}$ & -- & $\mathrm{x}$ & $\mathrm{x}$ & -- & -- & -- & -- & $\mathrm{x}$ & -- & $\mathrm{x}$ & $\mathrm{x}$ \\
\hline $68 \mathrm{~A}$ & $\mathrm{M}_{3}^{\mathrm{R}}$ & -- & -- & $\mathrm{x}$ & -- & -- & -- & -- & $\mathrm{x}$ & -- & $\mathrm{x}$ & $\mathrm{x}$ \\
\hline $69 \mathrm{~A}$ & $\mathrm{M}_{3}^{\mathrm{R}}$ & -- & $\mathrm{x}$ & $\mathrm{x}$ & -- & -- & -- & -- & $\mathrm{x}$ & -- & $\mathrm{x}$ & $\mathrm{x}$ \\
\hline
\end{tabular}

Stowell and others, 2001; Himmelberg and others, 2004). Where the plutons are widely spaced, these aureoles are well defined and grade from subgreenschist- to greenschist-facies $\left(\mathrm{M}_{1}^{\mathrm{R}}\right)$ country rocks to amphibolite-facies $\left(\mathrm{M}_{2}^{\mathrm{C}}\right)$ schists adjacent to the plutons. On the mainland south of the Stikine River (fig. 2), however, aureoles cannot be distinguished, a feature that has been attributed to high-grade regional metamorphism $\left(M_{2}^{R}\right)$ from numerous closely spaced plutons. Several studies interpreted this area to be overprinted by the $\mathrm{M}_{3}^{\mathrm{R}}$ (Barrovian) metamorphic event (Brew and others, 1984; Douglass and Brew, 1985; Stowell and Crawford, 2000; Himmelberg and others, 2004).

$\mathrm{M}_{2}^{\mathrm{C}}$ contact-metamorphic aureole rocks adjacent to the plutons, and regionally affected $\mathrm{M}_{2}^{\mathrm{R}}$ metamorphic rocks on the mainland, are amphibolite-facies grade, characterized by the pelitic assemblage quartz-plagioclase-biotite-garnet-staurolite \pm muscovite \pm kyanite \pm sillimanite.

Relict andalusite or pseudomorphs of andalusite replaced by one or more of the minerals kyanite, sillimanite, staurolite, muscovite, and biotite are present in some discrete aureole samples (see Douglass and Brew, 1985; Chace and Stowell, 1996; Stowell and Crawford, 2000; Himmelberg and others, 2004). However, neither andalusite nor pseudomorphs of andalusite have been observed in $\mathrm{M}_{2}^{\mathrm{R}}$ metamorphic rocks on the mainland. Relict kyanite enclosed in muscovite occurs in some samples of mainland rocks.

Andalusite replaced by kyanite and (or) sillimanite also has been reported in contact-metamorphic aureoles of the Admiralty-Revillagigedo plutonic belt south of Petersburg about the Eaton Point and Bell Island plutons (Cook and Crawford, 1994). Farther south, in the Ketchikan, AlaskaPrince Rupert, British Columbia, area (Crawford and others, 1987; Cook and Crawford, 1994) and to the north about the
Grand Island pluton on the northern part of Admiralty Island (Stowell and Inman, 1991; Inman, 1992), only kyanite or sillimanite is present in aureoles of these plutons.

The $\mathrm{M}_{3}^{\mathrm{R}}$ (Barrovian) metamorphic event in the Petersburg area (fig. 2) is defined by schists on the east side of Frederick Sound that display progressive isograds of garnet, staurolite, kyanite, and sillimanite (Douglass and Brew, 1985). The isograds are best defined on the mainland north of the Stikine River (fig. 2). South of the river, recognition of Barrovian isograds has been complicated by uncertainty as to whether the index minerals were produced by the $\mathrm{M}_{2}^{\mathrm{R}}$ or $\mathrm{M}_{3}^{\mathrm{R}}$ metamorphic event (fig. 2; Brew and others, 1989). Brew and others $(1989,1992)$ and Himmelberg and others (1991, 1994a, b) attributed the Barrovian regional metamorphism in the Juneau area to heat flow associated with plutons of the great tonalite sill. In other areas, other workers (McClelland and others, 1991; Stowell and Crawford, 2000) attributed the Barrovian regional metamorphism to crustal thickening associated with thrusting before emplacement of the plutons of the great tonalite sill; metamorphism associated with the emplacement of these plutons was interpreted as a later, separate contact-metamorphic $\left(\mathrm{M}_{4}^{\mathrm{C}-\mathrm{R}}\right)$ event superimposed on the Barrovian metamorphic event (Stowell and Crawford, 2000). No andalusite or andalusite pseudomorphs were observed in the Barrovian schists.

The locations of samples selected for mineral analysis and thermobarometric calculations are shown in figure 2, and the metamorphic-mineral assemblages in these samples are summarized in table 1. Sample selection was based on the presence of mineral assemblages useful for thermobarometry, mineralogic and textural indications of equilibrium among the phases used for thermobarometry, and minimum retrograde alteration of any phases. 


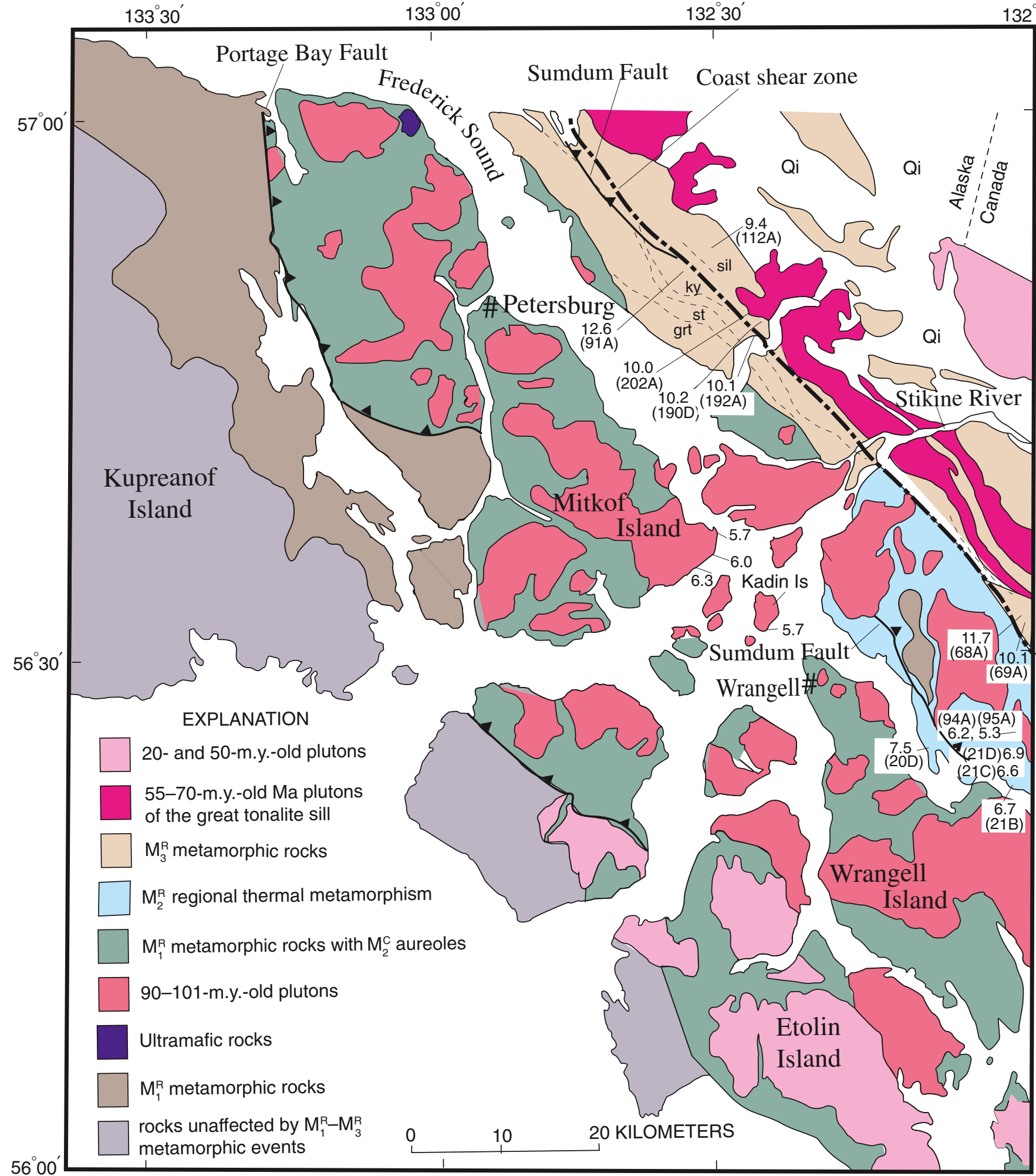

Figure 2. Geologic map of part of the Petersburg 1:250,000-scale quadrangle, southeastern Alaska, showing plutons, metamorphic effects, Barrovian isograds (grt, garnet; ky, kyanite; sil, sillimanite; st, staurolite) and calculated pressures (in kilobars), and samples (numbers in parentheses). Modified from Brew and others (1984) and Karl and others (1999). Calculated pressures on Mitkof and Kadin Islands from Himmelberg and others (2004). 
Electron-microprobe analyses of the garnet, biotite, plagioclase, muscovite, hornblende, and clinopyroxene used in thermobarometric calculations are listed in tables 2 through 6. Analyses of plagioclase, hornblende, biotite, muscovite, and clinopyroxene are for matrix grains not in contact with garnet. No significant compositional zoning or intergrain compositional differences were detected in hornblende, biotite, and muscovite; and compositional variation in plagioclase is minor in most samples. The difference in core and rim compositions is generally less than $\mathrm{An}_{1}$ except for samples $202 \mathrm{~A}$, in which the rim is about $\mathrm{An}_{1.4}$ greater than the core, and sample $68 \mathrm{~A}$, in which the rim is $\mathrm{An}_{2.2}$ less than the core. Representative garnet compositional profiles are plotted in figure 3. Most core-torim garnet compositional profiles exhibit zoning patterns typical of homogenization by high-temperature intracrystalline diffusion, as illustrated by sample $21 \mathrm{C}$ in figure 3 . Some samples, however, have bell-shaped spessartine compositional profiles typical of growth zoning, although the pyrope, grossular, and $\mathrm{Fe} /(\mathrm{Fe}+\mathrm{Mg})$ compositional profiles are essentially flat (sample 95A, fig. 3). Reversal of $\mathrm{Fe} /(\mathrm{Fe}+\mathrm{Mg}$ ) compositional profiles near the garnet rim for many samples suggests limited reequilibration during cooling (fig. 3 ).

\section{Thermobarometry}

Thermobarometric calculations (table 7), using the THERMOCALC program (Powell and Holland, 1988), were made with version 3.1 of the program and the internally consistent thermodynamic dataset HP98 (Holland and Powell 1998) updated in 2001. Mineral end-member activities were calculated by using the Ax program provided with THERMOCALC 3.1. Details of the activity models are given in the documentation provided with the THERMOCALC program (see T.J.B. Holland's Web page at URL http://www.esc.cam. as.uk/astaff/holland/), and for some mineral groups by Holland and Powell. The program was run in average $\mathrm{P}-\mathrm{T}$ mode to give the best-fit pressure and temperature. The THERMOCALC program generates uncertainties based on the propagation of both experimental and analytical errors (table 7). The
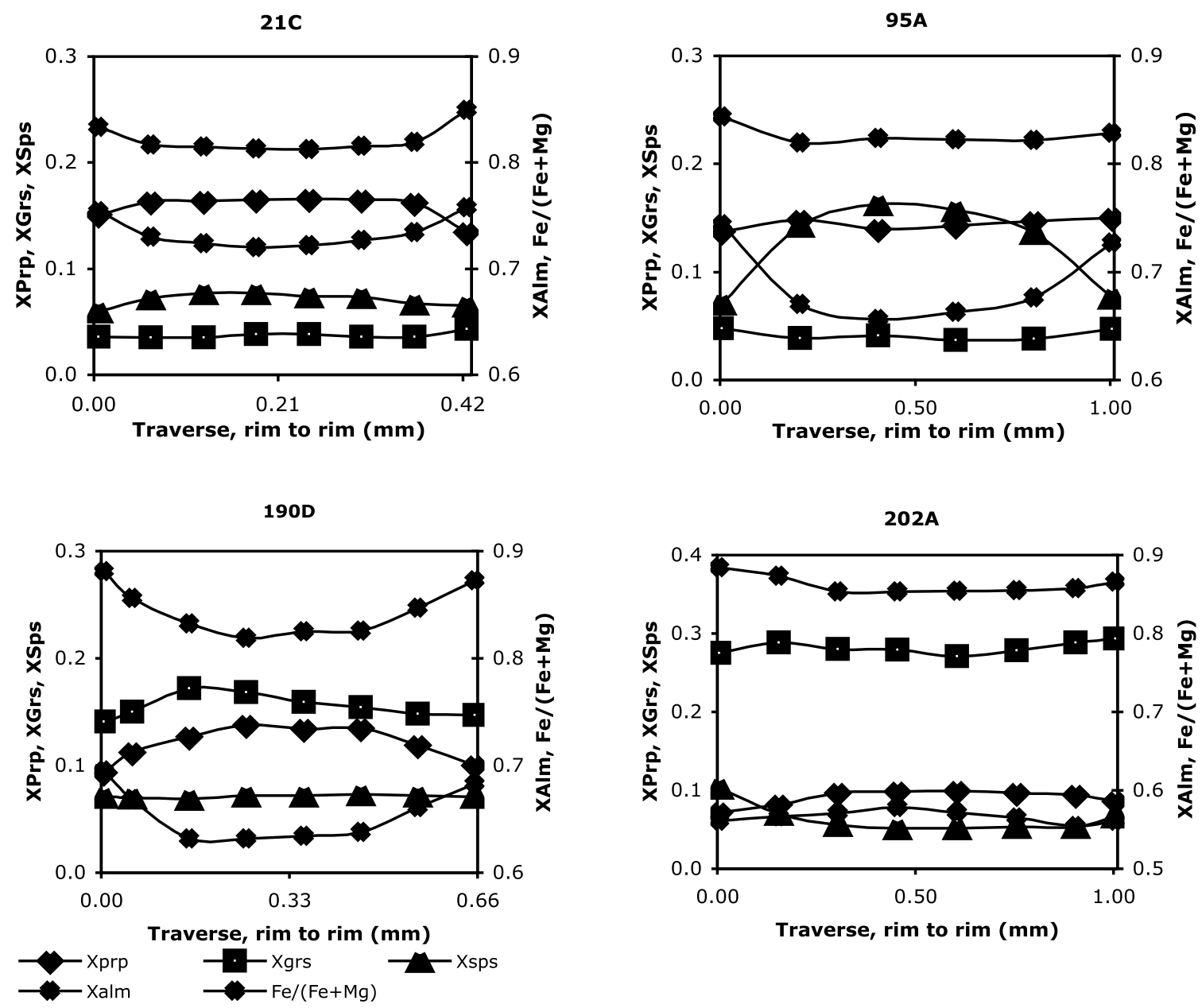

Figure 3. Representative compositional-zoning profiles for analyzed garnet in pelitic samples of $M_{2}^{R}(21 C, 95 A$, table 1) and $M_{3}^{R}$ (190D, 202A) metamorphic rocks of the Petersburg area, southeastern Alaska (see fig. 2 for locations). Normative minerals: Alm, almandine; Grs, grossular; Prp, pyrope; Sps, spessartine. 
Table 2. Chemical composition of garnet in samples of metamorphic rocks.

[All results obtained with the JEOL superprobe in the laboratory of Washington University, St. Louis, Mo; matrix corrections made by using a modified CITZAF analytical routine of Armstrong (1988). Total Fe calculated as FeO. Normative minerals: Alm, almondine; Grs, grossular; Prp, pyrope; Sps, spessartine. n.d., not detected]

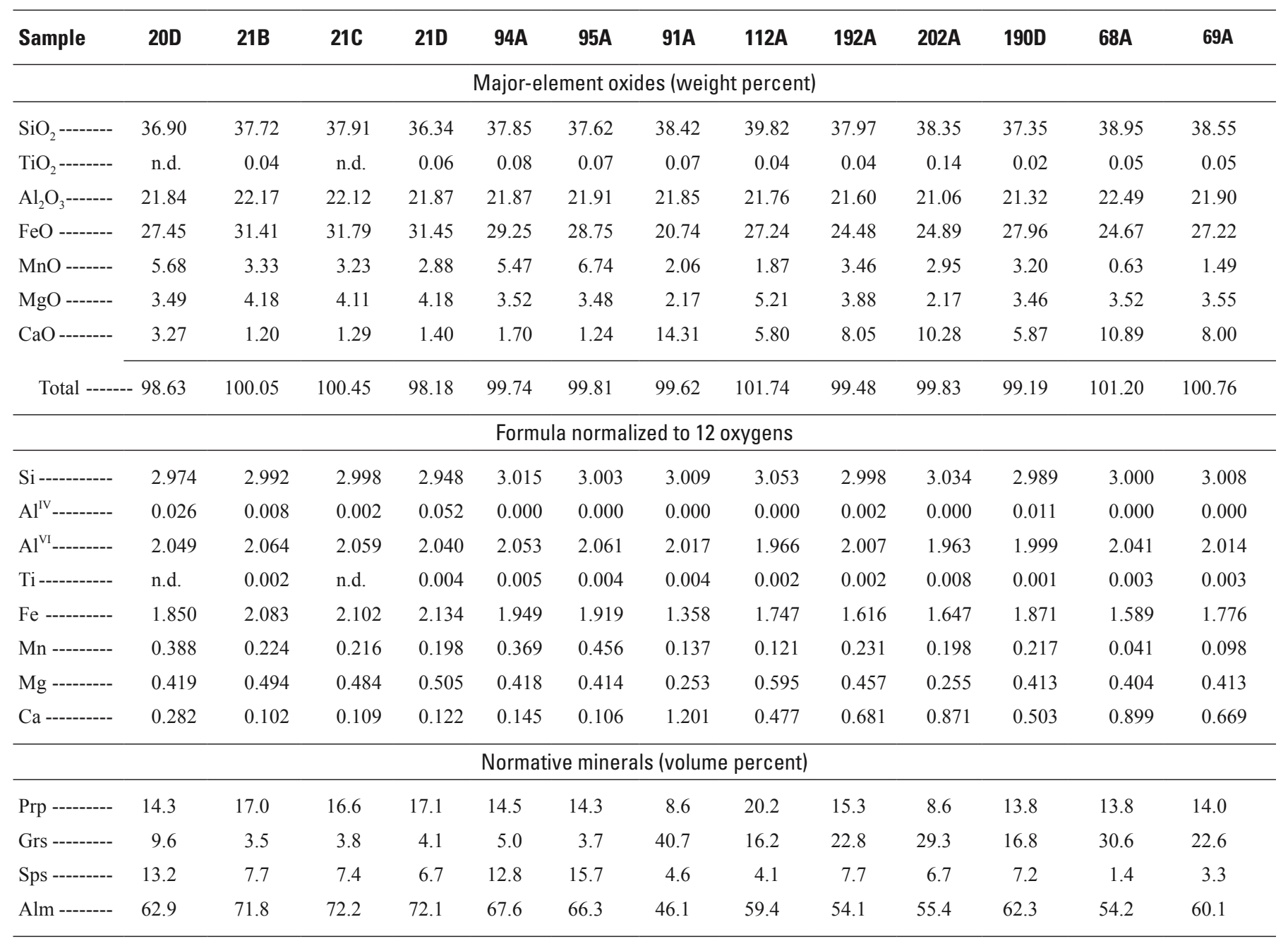

correlated P-T uncertainties allow an error ellipse to be plotted (fig. 4; Powell and Holland, 1988). As a result of using a single method with an internally consistent thermodynamic database, the resulting $\mathrm{P}-\mathrm{T}$ values are directly comparable to each other.

For those garnets exhibiting growth-zoning patterns, $\mathrm{P}-\mathrm{T}$ values were calculated by using rim compositions, or near-rim compositions for those garnets that showed rim reequilibration during cooling. For garnet crystals with high-temperature-diffusion homogenized patterns, core compositions were used. Garnet rim points in contact with hornblende or biotite were avoided, and analyses of obvious retrograded garnet points were omitted. Matrix biotite, hornblende, and plagioclase compositions were used in all samples. Rim compositions were used for plagioclase. Although we cannot demonstrate chemical equilibrium of the mineral assemblages used in the thermodynamic calculations, no evidence of nonequilibrium was observed. Textural equilibrium of the prograde mineral assemblages, and the relative chemical homogeneity of matrix grains and garnet near-rim compositions, all argue favorably for an approach to chemical equilibrium.

A significant difference exists between the $\mathrm{P}-\mathrm{T}$ values calculated for mineral assemblages formed during the $\mathrm{M}_{2}^{\mathrm{C}-\mathrm{R}}$ and $\mathrm{M}_{3}^{\mathrm{R}}$ metamorphic events, respectively (fig. 4; table 7). Spear (1991) demonstrated that garnets which achieved peak temperatures above about $550^{\circ} \mathrm{C}$ are invariably modified by diffusion during cooling. Thus, some of the differences in calculated temperatures and, therefore, pressures between mineral assemblages formed during the same metamorphic event may reflect different degrees of postpeak compositional modification. However, the significant difference in the $\mathrm{P}-\mathrm{T}$ values calculated for $\mathrm{M}_{2}^{\mathrm{C}-\mathrm{R}}$ and $\mathrm{M}_{3}^{\mathrm{R}}$ metamorphic-mineral assemblages, with little or no overlap of error ellipses (fig. 4), cannot adequately be explained by this process. Thus, we propose that the $\mathrm{P}-\mathrm{T}$ values calculated for $\mathrm{M}_{2}^{\mathrm{C}-\mathrm{R}}$ and $\mathrm{M}_{3}^{\mathrm{R}}$ metamorphic- 
mineral assemblages reflect near-peak conditions and that the conditions for these two events differed significantly. On that basis, we interpret that the peak or near-peak $\mathrm{P}-\mathrm{T}$ conditions for $\mathrm{M}_{2}^{\mathrm{R}}$ contact-metamorphic aureoles of the Admiralty-Revillagigedo plutonic belt were in the ranges 5.3-7.5 kbars and $580-640^{\circ} \mathrm{C}$ and that the peak or near-peak $\mathrm{P}-\mathrm{T}$ conditions for $\mathrm{M}_{3}^{\mathrm{R}}$ (Barrovian) metamorphic-mineral assemblages were in or near the ranges $9.4-12.6 \mathrm{kbars}$ and $730-895^{\circ} \mathrm{C}$. The $\mathrm{P}-\mathrm{T}$ conditions calculated for discrete $\mathrm{M} 2 \mathrm{C}$ metamorphic aureoles on Mitkof and Kadin Islands by Himmelberg and others (2004) were in the ranges $5.7-6.3 \mathrm{kbars}$ and $525-635^{\circ} \mathrm{C}$. These data illustrate no significant difference in the peak $\mathrm{P}-\mathrm{T}$ conditions of discrete $\mathrm{M}_{2}^{\mathrm{C}}$ contact-metamorphic aureoles and regional $\mathrm{M}_{2}^{\mathrm{R}}$ metamorphic rocks caused by intrusion of the AdmiraltyRevillagigedo plutonic belt.

\section{Summary of Metamorphic History: P-T Path}

\section{Timing of Metamorphic Events}

In general, available radiometric ages indicate that the $\mathrm{M}_{2}^{\mathrm{C}-\mathrm{R}}$ metamorphic event predated the $\mathrm{M}_{3}^{\mathrm{R}}$ (Barrovian) metamorphic event, although the timing of these events may have overlapped in some areas. Plutons of the Admiralty-Revillagigedo plutonic belt were emplaced from 101 to $83 \mathrm{Ma}$ (Douglass and others, 1989; Gehrels and others, 1992; McClelland and Mattinson, 2000). In the study area (figs. 1, 2), the timing of emplacement is constrained by discordant $\mathrm{U}-\mathrm{Pb}$ zircon ages of about 93 m.y. from southeastern Mitkof Island and about 91 m.y. from LeConte Bay (McClelland and others, 1992). The pluton at Garnet Ledge (fig. 2), which is in the $\mathrm{M}_{2}^{\mathrm{R}}$ metamorphic belt of this study, yields a concordant $\mathrm{U}-\mathrm{Pb}$ zircon age of $91.6 \mathrm{~m} . \mathrm{y}$., and garnet from the aureole of this pluton yields a Sm-Nd isochron age of about 89 m.y. (Stowell and others, 2001). Stowell and others reported that the peak P-T conditions of metamorphism for these rocks were in the ranges 6.1-6.3 kbars and $678-685^{\circ} \mathrm{C}$, consistent with our results for the $\mathrm{M}_{2}^{\mathrm{R}}$ metamorphic belt.

No radiometric ages constrain the timing of the $\mathrm{M}_{3}^{\mathrm{R}}$ metamorphic event in the study area (figs. 1,2), and overall, the timing of the Barrovian metamorphic event is poorly documented. Sutter and Crawford (1985) cited an ${ }^{40} \mathrm{Ar} /{ }^{39} \mathrm{Ar}$ age of $90 \pm 1 \mathrm{~m} . \mathrm{y}$. for metamorphic actinolitic amphibole from amphibolite-facies rocks near Prince Rupert, British Columbia. Stowell and Crawford (2000) interpreted the actinolite age as the timing of the $\mathrm{M}_{3}^{\mathrm{R}}$ metamorphic event, which would make it later than, or approximately coeval with, emplacement of the Ecstall pluton of the Admiralty-Revillagigedo plutonic belt (U-Pb zircon age, 98 \pm 4 m.y.; Sutter and Crawford, 1985; $\sim 91 \mathrm{Ma}$, G.E. Gehrels, in Stowell and Crawford, 2000). Stowell and Goldberg (1997) obtained Sm-Nd garnet ages of about $80 \pm 9$ and $77 \pm 17$ m.y. from $\mathrm{M}_{3}^{\mathrm{R}}$ metamorphic rocks in the areas of Tracy Arm and Taku Inlet, respectively (fig. 1). These ages are younger than the ${ }^{40} \mathrm{Ar}{ }^{39} \mathrm{Ar}$ amphibole age cited above, but considering the large errors associated with the $\mathrm{Sm}-\mathrm{Nd}$ ages, the difference may not be significant, or, as pointed out by Stowell and Goldberg (1997) the Sm-Nd garnet age of the rocks from Tracy Arm may reflect postpeak garnet growth, and the Sm-Nd age of the rocks from Taku Inlet may reflect reequilibration during the $\mathrm{M}_{4}^{\mathrm{C}-\mathrm{R}}$ metamorphic event associated with emplacement of the Mount Juneau pluton of the great tonalite sill (71.2 $\pm 1 \mathrm{Ma}$; Gehrels and others, 1991). Thus, although the timing of the $\mathrm{M}_{3}^{\mathrm{R}}$ metamorphic event remains uncertain, it may not differ significantly from that of the $\mathrm{M}_{2}^{\mathrm{C}-\mathrm{R}}$ metamorphic event.

Both the $\mathrm{M}_{2}^{\mathrm{R}}$ and $\mathrm{M}_{3}^{\mathrm{R}}$ metamorphic events apparently postdate the Sumdum Fault (fig. 2), a major mid-Cretaceous thrust fault north and east of Petersburg (fig. 1; McClelland and Mattinson, 2000). Separate mapping of Barrovian isograds by Douglass and Brew (1985) and of the Sumdum Fault by McClelland and Mattinson (2000) suggests that the isograds are continuous across the fault and that the fault is cut by the Admiralty-Revillagigedo plutonic belt. These geologic relations, which are consistent with the ages reported above, indicate that, indeed, an earlier, mid-Cretaceous $\mathrm{M}_{1}^{\mathrm{R}}$ metamorphic event was associated with the Sumdum Fault (McClelland and Mattinson, 2000).

\section{$M_{2}^{C}$ and $M_{2}^{R}$ Metamorphic Events}

Interpreted $\mathrm{P}-\mathrm{T}$ paths for the various metamorphic events are plotted in figure 5. The common occurrence of andalusite partly replaced by kyanite and (or) sillimanite in the island aureoles suggests near-isobaric heating of $\mathrm{M}_{1}^{\mathrm{R}}$ metamorphic country rocks under low-pressure conditions, followed by crustal thickening and higher-pressure metamorphism (solid gray line, fig. 4). Thermobarometry of these aureole rocks yields pressures ranging from about 5.7 to $6.3 \mathrm{kbars}$, consistent with the occurrence of kyanite and sillimanite (Himmelberg and others, 2004). Metamorphic-mineral assemblages from other Admiralty-Revillagigedo pluton aureoles south of Petersburg, and pluton-emplacement pressures obtained by using $\mathrm{Al}$ in hornblende, are consistent with these determinations (Cook and others, 1991; Cook and Crawford, 1994; Karen Inman, in Stowell and Crawford, 2000; Stowell and Crawford, 2000). On the basis of the parallelism between country-rock fabrics, hightemperature magmatic fabrics, and high- and low-temperature solid-state fabrics of distinct aureoles within and at the margins of the Admiralty-Revillagigedo plutonic belt, Himmelberg and others (2004) argued that crustal thickening was accomplished by thrusting during emplacement and cooling of the plutons. The restriction of high-P-T minerals to the aureoles, and the persistence of low-grade-mineral associations in the country rocks outside the aureoles, indicate that crustal thickening did not cause regional heating to high temperatures.

In contrast to the western $\mathrm{M}_{2}^{\mathrm{C}}$ metamorphic rocks from the islands, samples of $\mathrm{M}_{2}^{\mathrm{R}}$ metamorphic rocks from the mainland contain no evidence of metamorphosis at shallow crustal levels consistent with the andalusite stability field. Neither 
andalusite nor pseudomorphs of andalusite were observed. Thus, it is unclear whether the $\mathrm{P}-\mathrm{T}$ path of the $\mathrm{M}_{2}^{\mathrm{R}}$ metamorphic event on the mainland was the same as that of the $\mathrm{M}_{2}^{\mathrm{C}}$ metamorphic event or whether, on the mainland, crustal thickening occurred before emplacement of the plutons, so that the intrusion and associated heating responsible for the $\mathrm{M}_{2}^{\mathrm{R}}$ metamorphic event occurred entirely at depths consistent with kyanite-sillimanite stability (dashed gray path labeled " $\mathrm{M}_{2}^{\mathrm{R}}$ alternative possibility," fig. 5). If the second interpretation is correct, then the plutons on the mainland were emplaced later, and at a deeper crustal level, than those to the west. The available radiometric data are insufficient to confirm this interpretation. The relict kyanite in some samples of $\mathrm{M}_{2}^{\mathrm{R}}$ metamorphic rocks from the mainland may be a result of the prograde transition from kyanite to sillimanite stability fields or of decompression following peak metamorphism.

\section{$\mathbf{M}_{3}^{\mathrm{R}}$ (Barrovian) Metamorphism}

The Barrovian metamorphic belt in the Petersburg area (fig. 1) records an eastward increase in grade. Douglass and Brew (1985) mapped garnet, staurolite, kyanite, and silliman- ite isograds (fig. 2). No andalusite has been observed in the Barrovian metamorphic belt throughout southeastern Alaska. Our thermobarometry on kyanite- and sillimanite-zone pelitic schists and garnet amphibolites yielded pressures ranging from about 9.1 to 12.6 kbars (table 7). McClelland and others (1991) obtained similarly high pressures for some of the samples in their study, consistent with the pressure obtained for the Barrovian metamorphic belt in the vicinity of Juneau (fig. 1; Himmelberg and others, 1991, 1994a). Stowell (1989) obtained substantially lower pressures (4-5 kbars) for equivalent rocks in the Holkham Bay area between Petersburg and Juneau; however, G.R. Himmelberg (unpub. data, 1994) obtained a pressure of $8.5 \mathrm{kbars}$ for a garnet amphibolite from that area.

Barrovian metamorphism of the western metamorphic belt has been attributed either to regional metamorphism during thrusting or to heat advected during emplacement of plutons of the great tonalite sill. McClelland and others (1991) interpreted the Barrovian metamorphic event through the kyanite zone in the Petersburg area (fig. 1) to be synchronous with movement on the mid-Cretaceous Sumdum-Fanshaw thrust-fault system, one of the major westward-directed thrust faults on the west side of the Coast Mountains. As described

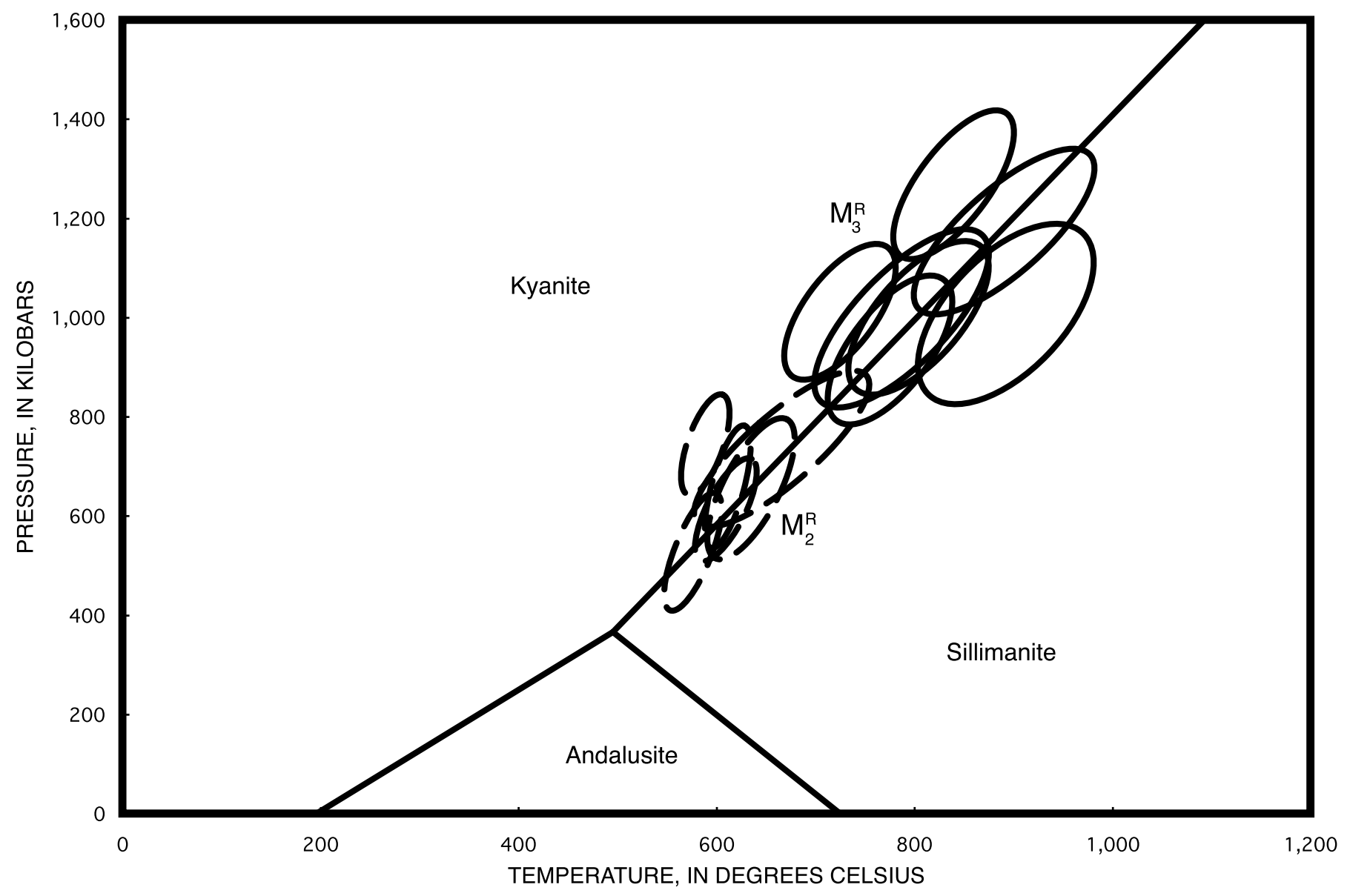

Figure 4. Pressure-temperature estimates for samples of metamorphic rocks, calculated with THERMOCALC software (Powell and Holland, 1988). Error ellipses represent standard deviations: dashed, $\mathrm{M}_{2}^{\mathrm{R}}$ metamorphic rocks; solid, $\mathrm{M}_{3}^{\mathrm{R}}$ metamorphic rocks. $\mathrm{Al}_{2} \mathrm{SiO}{ }_{5}$ triple point from Holdaway (1971). 


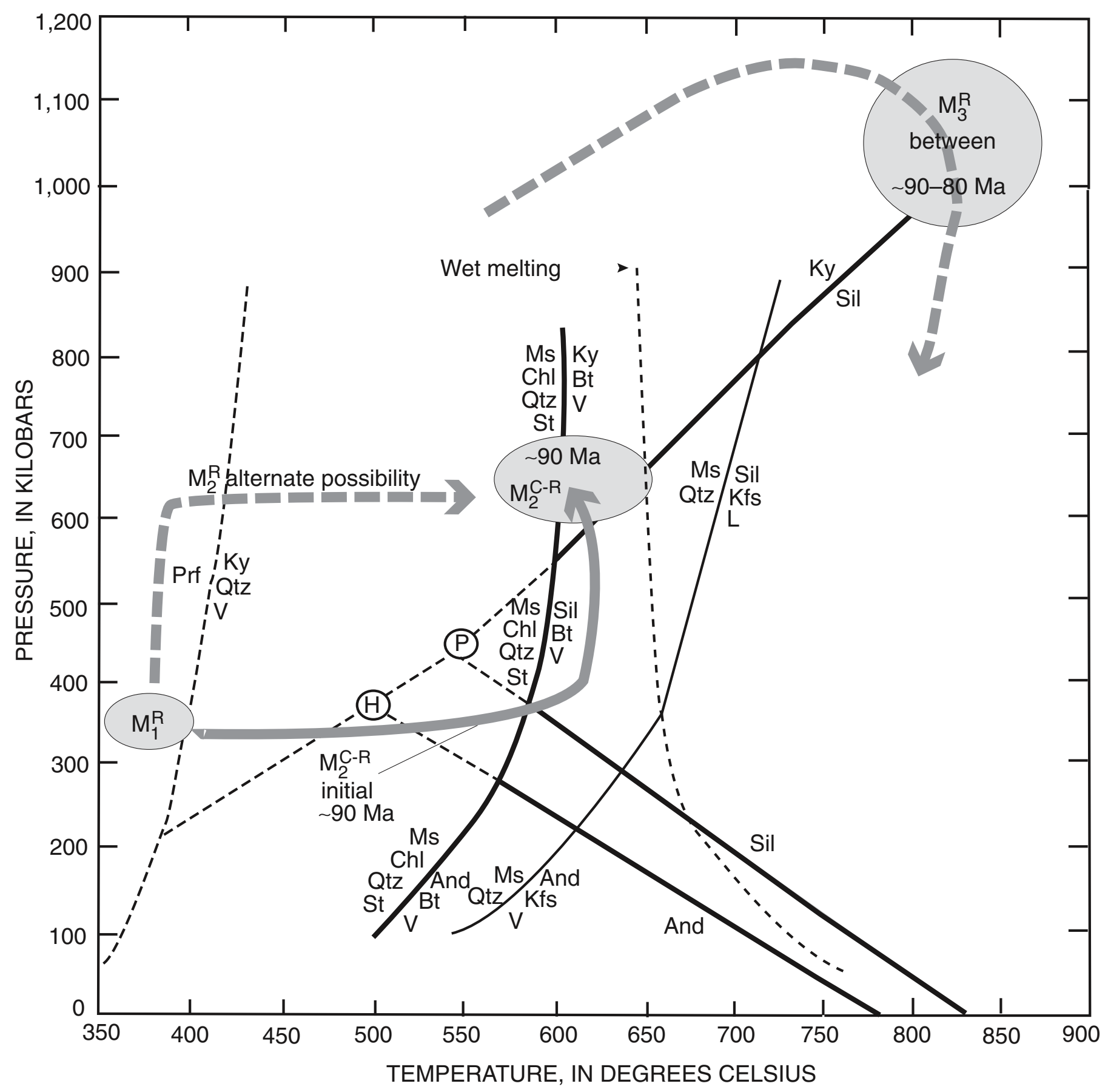

Figure 5. Interpreted pressure-temperature (P-T) paths for $\mathrm{M}_{2}^{\mathrm{C}-\mathrm{R}}$ metamorphic aureoles (solid gray arrow) and $\mathrm{M}_{3}^{\mathrm{R}}$ (Barrovian) metamorphic rocks (high-pressure dashed gray arrow). Center of $\mathrm{M}_{2}^{\mathrm{C}-\mathrm{R}}$ and $\mathrm{M}_{3}^{\mathrm{R}}$ ellipses is average $\mathrm{P}-\mathrm{T}$ value for respective events; radii of ellipses approximately equal standard deviation. See figure 3 for error ellipses of each sample. Alternative $\mathrm{P}-\mathrm{T}$ path for $\mathrm{M}_{2}^{\mathrm{C}-\mathrm{R}}$ metamorphic event is also shown (low-pressure dashed gray arrow). $\mathrm{P}-\mathrm{T}$ path for the $\mathrm{M}_{2}^{\mathrm{C}-\mathrm{R}}$ metamorphic event modified from Himmelberg and others (2004). P-T conditions for the M1R metamorphic event are approximate and based on mineral assemblages. P-T diagram modified from Pattison (2001). L, liquid; $\mathrm{V}$, vapor. Circled $\mathrm{H}, \mathrm{Al}_{2} \mathrm{SiO}_{5}$ triple point of Holdaway (1971); circled $\mathrm{P}, \mathrm{Al}_{2} \mathrm{SiO}_{5}$ triple point of Pattison (1992). Metamorphic minerals: And, andalusite; Bt, biotite; Chl, chlorite; Kfs, K-feldspar; Ky, kyanite; Ms, muscovite; Prf, pyrophyllite; Qtz, quartz; Sil, sillimanite; St, staurolite. According to Pattison (2001), $\mathrm{P}-\mathrm{T}$ values to right of $\mathrm{Ms}+\mathrm{Chl}+\mathrm{Otz}+\mathrm{St}=\mathrm{Al}_{2} \mathrm{SiO}_{5}+\mathrm{Bt}+\mathrm{V}$ equation must be obtained for $\mathrm{Al}_{2} \mathrm{SiO}_{5}$ polymorphs to occur in $\mathrm{Ms}+\mathrm{Bt}+\mathrm{Qtz}$-bearing rocks. 
Table 3. Chemical composition of biotite in samples of metamorphic rocks.

[All results obtained with the JEOL superprobe in the laboratory of Washington University, St. Louis, Mo; matrix corrections made by using a modified CITZAF analytical routine of Armstrong (1988). Total Fe calculated as FeO; n.d., not detected]

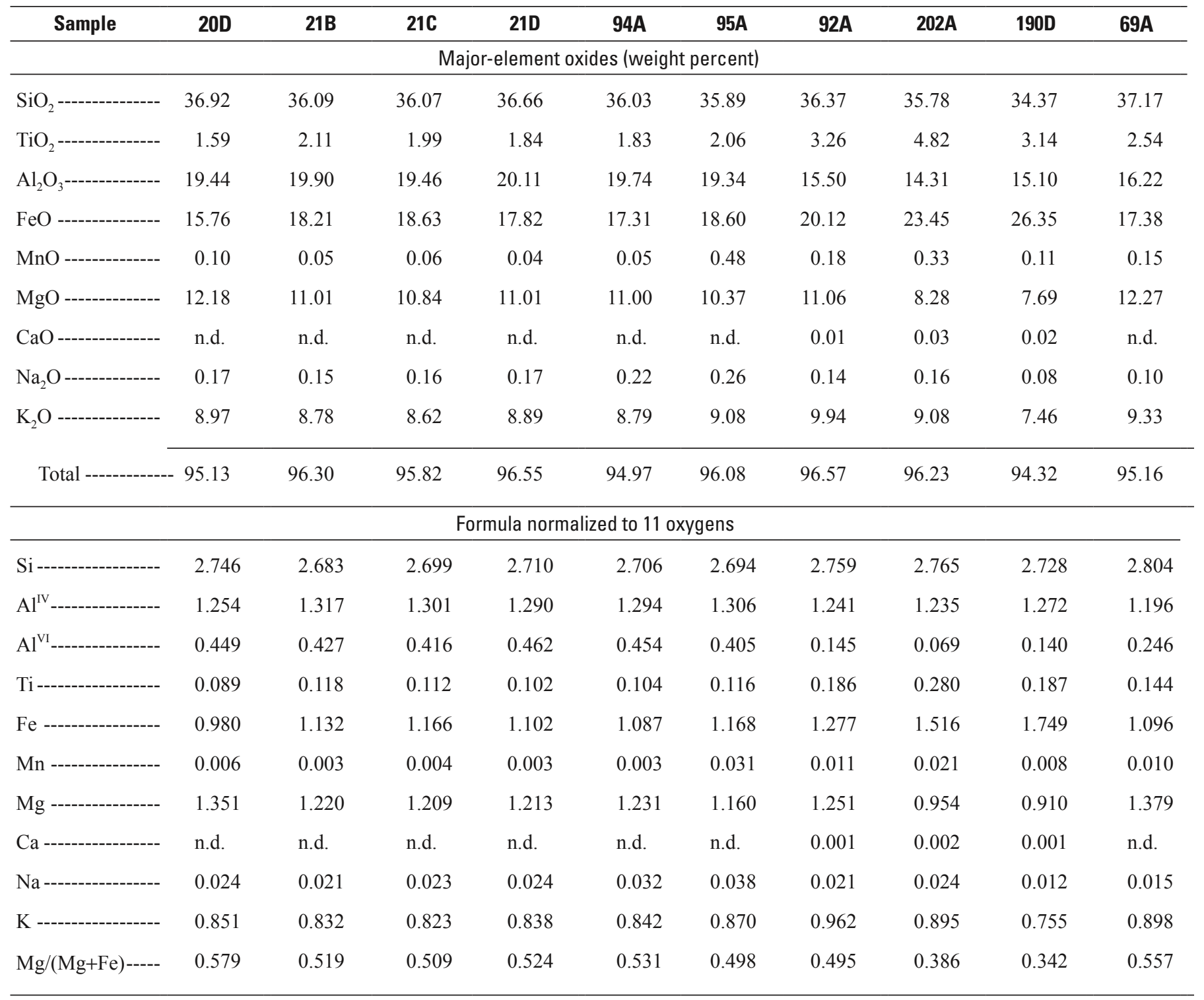

previously, however, movement on this fault system predated the emplacement of plutons of the Admiralty-Revillagigedo plutonic belt and the $\mathrm{M}_{2}^{\mathrm{C}-\mathrm{R}}$ and $\mathrm{M}_{3}^{\mathrm{R}}$ metamorphic events. McClelland and others (1991) attributed sillimanite-zone metamorphism along the east edge of the western metamorphic belt as contact metamorphism $\left(\mathrm{M}_{4}^{\mathrm{C}-\mathrm{R}}\right)$ caused by emplacement of the Late Cretaceous to Paleocene (58-72 m.y. old) plutons of the great tonalite sill. Stowell and Crawford (2000) advanced a similar interpretation in their summary of the history of the western metamorphic belt throughout southeastern Alaska and British Columbia. Brew and others $(1989,1992)$ and Himmelberg and others (1991) attributed the Barrovian garnet- through sillimanite- grade metamorphism along the east side of the western metamorphic belt in the Juneau area to advection of heat from plutons of the great tonalite sill (58-72 m.y. old). Stowell and Crawford (2000) acknowledged that in the northern part of the belt, regional metamorphism associated with thrusting is difficult to distinguish from contact metamorphism associated with the great tonalite sill. The P-T path for the $\mathrm{M}_{3}^{\mathrm{R}}$ metamorphic event plotted in figure 5 (upper dashed gray line) assumes heating as a result of crustal thickening, consistent with the $\mathrm{P}-\mathrm{T}$ paths created by modeling of orogenic belts (Spear, 1993).

In the Petersburg area (fig. 1), calculated pressures for the kyanite $\left(\mathrm{M}_{3}^{\mathrm{R}}\right)$ and sillimanite $\left(\mathrm{M}_{4}^{\mathrm{C}-\mathrm{R}}\right)$ zones do not differ significantly (fig. 2; table 7). Thus, if the sillimanite-zone schists and gneisses are a result of contact metamorphism by the great tonalite sill, as advocated by McClelland and others (1991) 
[All results obtained with the JEOL superprobe in the laboratory of Washington University, St. Louis, Mo; matrix corrections made by using a modified CITZAF analytical routine of Armstrong (1988). Total Fe calculated as $\mathrm{FeO}]$

\begin{tabular}{|c|c|c|c|c|c|c|c|c|c|c|c|c|c|}
\hline Sample & 20D & 21B & $21 C$ & 21D & 94A & 95A & $91 \mathrm{~A}$ & $112 A$ & $192 A$ & 202A & 190D & $68 \mathrm{~A}$ & $69 \mathrm{~A}$ \\
\hline \multicolumn{14}{|c|}{ Major-element oxides (weight percent) } \\
\hline $\mathrm{SiO}_{2}$ & 60.50 & 61.94 & 63.02 & 62.27 & 61.81 & 62.46 & 57.42 & 60.97 & 59.47 & 56.76 & 61.77 & 55.83 & 58.58 \\
\hline $\mathrm{Al}_{2} \mathrm{O}_{3}--\cdot----$ & 24.96 & 23.36 & 23.58 & 23.99 & 23.92 & 23.63 & 27.26 & 25.02 & 25.43 & 27.31 & 24.34 & 28.86 & 26.51 \\
\hline FeO ------- & 0.07 & 0.13 & 0.18 & 0.11 & 0.11 & 0.07 & 0.20 & 0.08 & 0.10 & 0.10 & 0.05 & 0.06 & 0.24 \\
\hline $\mathrm{CaO}$-------- & 5.93 & 4.18 & 4.11 & 4.41 & 5.66 & 4.77 & 9.16 & 7.12 & 7.37 & 9.40 & 5.87 & 10.29 & 7.46 \\
\hline $\mathrm{Na}_{2} \mathrm{O}$------- & 8.02 & 9.05 & 9.10 & 8.92 & 8.46 & 8.93 & 6.41 & 7.90 & 7.61 & 6.46 & 8.39 & 5.79 & 7.34 \\
\hline $\mathrm{K}_{2} \mathrm{O}$------- & 0.05 & 0.08 & 0.07 & 0.07 & 0.08 & 0.09 & 0.21 & 0.03 & 0.07 & 0.15 & 0.25 & 0.14 & 0.18 \\
\hline Total ------- & 99.53 & 98.73 & 100.04 & 99.76 & 100.04 & 99.95 & 100.64 & 101.12 & 100.05 & 100.17 & 100.65 & 100.97 & 100.31 \\
\hline \multicolumn{14}{|c|}{ Formula normalized to 8 oxygens } \\
\hline Si ----------- & 2.699 & 2.775 & 2.783 & 2.761 & 2.742 & 2.767 & 2.561 & 2.687 & 2.653 & 2.547 & 2.727 & 2.489 & 2.612 \\
\hline Al --------- & 1.312 & 1.233 & 1.227 & 1.253 & 1.251 & 1.234 & 1.433 & 1.299 & 1.337 & 1.444 & 1.267 & 1.516 & 1.393 \\
\hline Fe --------- & 0.003 & 0.005 & 0.006 & 0.004 & 0.004 & 0.003 & 0.007 & 0.003 & 0.004 & 0.004 & 0.002 & 0.002 & 0.009 \\
\hline Ca --------- & 0.283 & 0.201 & 0.194 & 0.210 & 0.269 & 0.226 & 0.438 & 0.336 & 0.352 & 0.452 & 0.278 & 0.491 & 0.356 \\
\hline Na --------- & 0.693 & 0.786 & 0.779 & 0.766 & 0.728 & 0.767 & 0.554 & 0.675 & 0.659 & 0.562 & 0.718 & 0.500 & 0.634 \\
\hline K ---------- & 0.003 & 0.004 & 0.004 & 0.004 & 0.005 & 0.005 & 0.012 & 0.002 & 0.004 & 0.009 & 0.014 & 0.008 & 0.010 \\
\hline \multicolumn{14}{|c|}{ Normative minerals (volume percent) } \\
\hline An---------- & 28.9 & 20.2 & 19.9 & 21.4 & 26.9 & 22.7 & 43.6 & 33.2 & 34.7 & 44.2 & 27.5 & 49.2 & 35.6 \\
\hline Ab---------- & 70.8 & 79.3 & 79.7 & 78.2 & 72.7 & 76.8 & 55.2 & 66.6 & 64.9 & 54.9 & 71.1 & 50.1 & 63.4 \\
\hline Or ---------- & 0.3 & 0.4 & 0.4 & 0.4 & 0.5 & 0.5 & 1.2 & 0.2 & 0.4 & 0.8 & 1.4 & 0.8 & 1.0 \\
\hline
\end{tabular}


Table 5. Chemical composition of muscovite in samples of metamorphic rocks.

[All results obtained with the JEOL superprobe in the laboratory of Washington University, St. Louis, Mo; matrix corrections made by using a modified CITZAF analytical routine of Armstrong (1988). Total Fe calculated as FeO]

\begin{tabular}{|c|c|c|c|c|c|c|}
\hline Sample & 20D & 21B & $21 \mathrm{C}$ & 21D & 94A & $95 A$ \\
\hline \multicolumn{7}{|c|}{ Major-element oxides (weight percent) } \\
\hline $\mathrm{SiO}_{2}$------------ & 46.64 & 46.26 & 46.10 & 46.24 & 44.96 & 46.36 \\
\hline $\mathrm{TiO}_{2}$ & 0.64 & 0.74 & 0.83 & 0.66 & 0.60 & 0.66 \\
\hline $\mathrm{Al}_{2} \mathrm{O}_{3}$---------- & 35.91 & 36.50 & 36.12 & 36.14 & 37.64 & 36.77 \\
\hline FeO ----------- & 0.97 & 1.12 & 1.20 & 0.99 & 0.96 & 1.02 \\
\hline MgO --------- & 0.83 & 0.66 & 0.66 & 0.66 & 0.61 & 0.61 \\
\hline $\mathrm{Na}_{2} \mathrm{O}$---------- & 1.31 & 1.44 & 1.43 & 1.43 & 1.38 & 1.35 \\
\hline $\mathrm{K}_{2} \mathrm{O}$-------- & 8.95 & 8.89 & 8.74 & 8.73 & 8.89 & 9.22 \\
\hline Total----------- & 95.24 & 95.59 & 95.08 & 94.82 & 95.03 & 95.99 \\
\hline \multicolumn{7}{|c|}{ Formula normalized to 11 oxygens } \\
\hline Si ------------- & 3.077 & 3.045 & 3.050 & 3.062 & 2.978 & 3.041 \\
\hline $\mathrm{Al}^{\mathrm{IV}}-\mathrm{-}_{-}$ & 0.923 & 0.955 & 0.950 & 0.938 & 1.022 & 0.959 \\
\hline $\mathrm{Al}^{\mathrm{VI}}$------------ & 1.869 & 1.876 & 1.867 & 1.883 & 1.916 & 1.885 \\
\hline Ti----- & 0.032 & 0.036 & 0.041 & 0.033 & 0.030 & 0.033 \\
\hline Fe ----------- & 0.054 & 0.061 & 0.066 & 0.055 & 0.053 & 0.056 \\
\hline $\mathrm{Mg}-$ & 0.081 & 0.064 & 0.065 & 0.065 & 0.061 & 0.060 \\
\hline Na ------------ & 0.168 & 0.184 & 0.183 & 0.183 & 0.177 & 0.172 \\
\hline K ------------- & 0.753 & 0.746 & 0.738 & 0.737 & 0.751 & 0.772 \\
\hline \multicolumn{7}{|c|}{ Normative minerals (volume percent) } \\
\hline Ms------------- & 81.8 & 80.2 & 80.1 & 80.1 & 80.9 & 81.8 \\
\hline Pg ------------- & 18.2 & 19.8 & 19.9 & 19.9 & 19.1 & 18.2 \\
\hline
\end{tabular}

and Stowell and Crawford (2000), then this metamorphic event occurred at essentially the same depth as the kyanite $\left(\mathrm{M}_{3}^{\mathrm{R}}\right)$-zone regional metamorphism in the Petersburg area. Most of the samples of Barrovian metamorphic minerals from the Petersburg area used in thermobarometry, all of which are from schists and gneisses close to the Coast shear zone, yield high pressures (9.1-12.6 kbars).

\section{Discussion and Conclusions}

Over much of the Admiralty-Revillagigedo plutonic belt, especially along its western part, the high-temperature, moderate-pressure $\left(\mathrm{M}_{2}^{\mathrm{C}}\right)$ metamorphism is largely restricted to discrete aureoles surrounded by low-grade or greenschistfacies $\left(M_{1}^{R}\right)$ country rocks. No evidence suggests that these aureoles were involved in the $\mathrm{M}_{3}^{\mathrm{R}}$ metamorphic event (Douglass and Brew, 1985; Himmelberg and others, 2004). Although Douglass and Brew (1985) proposed that $\mathrm{M}_{2}^{\mathrm{R}}$ metamorphic rocks, which are related to plutons of the Admiralty-Revillagigedo plutonic belt on the mainland, were subsequently overprinted by the $\mathrm{M}_{3}^{\mathrm{R}}$ (Barrovian) metamorphic event, our thermobarometric data do not support their proposal. The Barrovian metamorphic event occurred under pressures of 9.1 to 12.6 kbars, whereas the metamorphic event $\left(M_{2}^{R}\right)$ associated with the emplacement of plutons of the Admiralty-Revillagigedo plutonic belt on the mainland yielded pressures of 5.3 to $7.5 \mathrm{kbars}$, about the same as those determined for discrete aureoles of the Admiralty-Revillagigedo plutonic belt to the 
Table 6. Chemical composition of hornblende and clinopyroxene in samples of metamorphic rocks.

[All results obtained with the JEOL superprobe in the laboratory of Washington University, St. Louis, Mo; matrix corrections made by using a modified CITZAF analytical routine of Armstrong (1988). Total Fe calculated as FeO]

\begin{tabular}{|c|c|c|c|c|c|c|c|c|}
\hline \multirow[b]{2}{*}{ Sample } & \multicolumn{7}{|c|}{ Hornblende } & \multirow{2}{*}{$\begin{array}{c}\begin{array}{c}\text { Clino- } \\
\text { pyroxene }\end{array} \\
91 \mathrm{~A}\end{array}$} \\
\hline & $91 \mathrm{~A}$ & $112 \mathrm{~A}$ & $192 A$ & 202A & 190D & $68 \mathrm{~A}$ & $69 A$ & \\
\hline \multicolumn{9}{|c|}{ Major-element oxides (weight percent) } \\
\hline 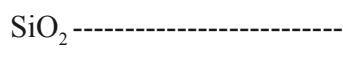 & 42.01 & 42.99 & 43.25 & 41.67 & 42.30 & 43.29 & 42.45 & 51.81 \\
\hline $\mathrm{TiO}_{2}$ & 0.70 & 1.27 & 1.27 & 2.01 & 1.37 & 1.09 & 1.41 & 0.00 \\
\hline 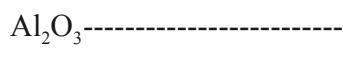 & 12.78 & 12.52 & 12.29 & 11.71 & 11.07 & 11.64 & 13.33 & 0.40 \\
\hline FeO ----------------------- & 19.04 & 18.40 & 16.65 & 20.50 & 23.21 & 18.69 & 16.31 & 13.57 \\
\hline MnO --------------'-------- & 0.34 & 0.31 & 0.43 & 0.51 & 0.41 & 0.21 & 0.25 & 0.60 \\
\hline MgO --------------------- & 7.93 & 10.14 & 9.90 & 6.96 & 6.65 & 8.89 & 9.79 & 10.14 \\
\hline $\mathrm{CaO}$------------------------' & 12.25 & 10.19 & 11.48 & 11.77 & 10.70 & 11.32 & 11.05 & 24.25 \\
\hline 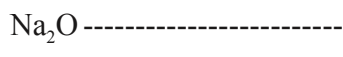 & 1.01 & 1.96 & 1.46 & 1.35 & 1.71 & 1.27 & 1.63 & 0.11 \\
\hline 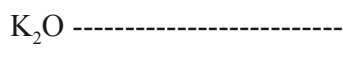 & 1.56 & 0.44 & 0.82 & 1.70 & 0.68 & 0.95 & 0.93 & -- \\
\hline Total-------------------- & 97.61 & 98.22 & 97.53 & 98.18 & 98.09 & 97.34 & 97.15 & 100.88 \\
\hline \multicolumn{9}{|c|}{$\begin{array}{l}\text { Hornblende formula normalized to } 13 \text { cations exclusive of } \mathrm{Ca} \text {, } \mathrm{Na} \text {, and } \mathrm{K} \text {; } \\
\text { clinopyroxene formula normalized to } 6 \text { oxygens }\end{array}$} \\
\hline Si --------------------------- & 6.376 & 6.244 & 6.408 & 6.376 & 6.389 & 6.475 & 6.293 & 1.975 \\
\hline 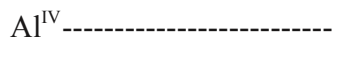 & 1.624 & 1.756 & 1.592 & 1.624 & 1.611 & 1.525 & 1.707 & 0.018 \\
\hline ------------------- & 0.663 & 0.388 & 0.554 & 0.490 & 0.360 & 0.528 & 0.623 & 0.000 \\
\hline 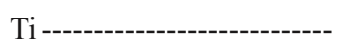 & 0.080 & 0.139 & 0.142 & 0.231 & 0.156 & 0.123 & 0.157 & 0.000 \\
\hline 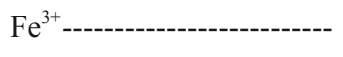 & 0.213 & 1.280 & 0.533 & 0.070 & 0.838 & 0.568 & 0.608 & -- \\
\hline $\mathrm{Fe}^{2+}$ & 2.205 & 0.956 & 1.531 & 2.555 & 2.095 & 1.772 & 1.415 & -- \\
\hline $\mathrm{Fe}_{\mathrm{T}}$ & 2.413 & 2.236 & 2.064 & 2.625 & 2.933 & 2.340 & 2.023 & 0.433 \\
\hline Mn ------------------------ & 0.043 & 0.038 & 0.054 & 0.065 & 0.052 & 0.026 & 0.032 & 0.019 \\
\hline Mg ----------'------------- & 1.795 & 2.198 & 2.187 & 1.588 & 1.499 & 1.983 & 2.165 & 0.576 \\
\hline Ca ----------------------- & 1.995 & 1.588 & 1.824 & 1.933 & 1.734 & 1.817 & 1.758 & 0.991 \\
\hline 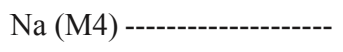 & 0.005 & 0.412 & 0.176 & 0.067 & 0.266 & 0.183 & 0.242 & -- \\
\hline 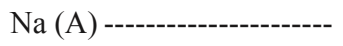 & 0.291 & 0.140 & 0.243 & 0.335 & 0.235 & 0.185 & 0.228 & -- \\
\hline 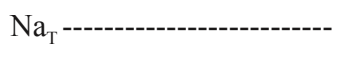 & 0.296 & 0.552 & 0.419 & 0.402 & 0.501 & 0.368 & 0.470 & 0.008 \\
\hline K ------------------------- & 0.302 & 0.081 & 0.156 & 0.333 & 0.131 & 0.181 & 0.177 & -- \\
\hline Mg ---------'----'--------- & -- & -- & -- & -- & -- & -- & -- & 28.8 \\
\hline 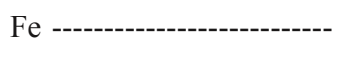 & -- & -- & -- & -- & -- & -- & -- & 21.6 \\
\hline Ca ----------------'------- & -- & -- & -- & -- & -- & -- & -- & 49.5 \\
\hline $\mathrm{Mg} /\left(\mathrm{Mg}+\mathrm{Fe}^{2+}+\mathrm{Mn}\right)$ & 0.444 & 0.689 & 0.580 & 0.377 & 0.411 & 0.525 & 0.599 & 0.560 \\
\hline
\end{tabular}


Table 7. Thermobarometric data for mineral assemblages in samples of $M_{2}^{R}$ and $M_{3}^{R}$ metamorphic rocks from the Petersburg area, southeastern Alaska, calculated with the THERMOCALC program.

\begin{tabular}{|c|c|c|c|c|c|c|c|c|}
\hline \multirow{2}{*}{ Sample } & \multirow{2}{*}{$\begin{array}{l}\text { Metamorphic } \\
\text { event }\end{array}$} & \multicolumn{2}{|c|}{$\begin{array}{c}\text { Temperature } \\
\left({ }^{\circ} \mathrm{C}\right)\end{array}$} & \multicolumn{2}{|c|}{$\begin{array}{c}\text { Pressure } \\
\text { (kbars) }\end{array}$} & \multicolumn{3}{|c|}{$\begin{array}{l}\text { Independent } \\
\text { reactions }\end{array}$} \\
\hline & & Avg & $\sigma$ & Avg & $\sigma$ & Fit & c.c. & No. \\
\hline $20 \mathrm{D}$ & $\mathrm{M}_{2}^{\mathrm{R}}$ & 595 & 28 & 7.5 & 1.1 & 0.46 & 0.77 & 5 \\
\hline $21 \mathrm{~B}$ & $\mathrm{M}_{2}^{\mathrm{R}}$ & 640 & 36 & 6.7 & 1.3 & 0.39 & 0.77 & 5 \\
\hline $21 \mathrm{C}$ & $\mathrm{M}_{2}^{\mathrm{R}}$ & 615 & 22 & 6.6 & 1.2 & 0.44 & 0.82 & 6 \\
\hline $21 \mathrm{D}$ & $\mathrm{M}_{2}^{\mathrm{R}}$ & 620 & 22 & 6.9 & 1.1 & 0.39 & 0.81 & 6 \\
\hline $94 \mathrm{~A}$ & $\mathrm{M}_{2}^{\mathrm{R}}$ & 610 & 30 & 6.2 & 1.1 & 0.17 & 0.75 & 5 \\
\hline $95 \mathrm{~A}$ & $\mathrm{M}_{2}^{\mathrm{R}}$ & 580 & 26 & 5.3 & 1.1 & 0.65 & 0.77 & 5 \\
\hline $91 \mathrm{~A}$ & $\mathrm{M}_{3}^{\mathrm{R}}$ & 840 & 62 & 12.6 & 1.5 & 0.69 & 0.60 & 6 \\
\hline $112 \mathrm{~A}$ & $\mathrm{M}_{3}^{\mathrm{R}}$ & 785 & 63 & 9.4 & 1.5 & 0.91 & 0.63 & 5 \\
\hline $192 \mathrm{~A}$ & $\mathrm{M}_{3}^{\mathrm{R}}$ & 800 & 77 & 10.1 & 1.6 & 1.12 & 0.66 & 7 \\
\hline $202 \mathrm{~A}$ & $\mathrm{M}_{3}^{\mathrm{R}}$ & 790 & 97 & 10.0 & 1.6 & 0.98 & 0.63 & 6 \\
\hline 190D & $\mathrm{M}_{3}^{\mathrm{R}}$ & 895 & 97 & 10.2 & 1.8 & 0.93 & 0.67 & 7 \\
\hline $68 \mathrm{~A}$ & $\mathrm{M}_{3}^{\mathrm{R}}$ & 895 & 93 & 11.7 & 1.6 & 0.70 & 0.69 & 5 \\
\hline $69 \mathrm{~A}$ & $M_{3}^{R}$ & 730 & 60 & 10.1 & 1.4 & 1.01 & 0.68 & 7 \\
\hline
\end{tabular}

west (Himmelberg and others, 2004). If the $M_{2}^{R}$ metamorphic rocks had been subjected to the same high temperatures and pressures as those of the Barrovian metamorphic event, the aureoles and interaureole country rocks would probably have more nearly equilibrated to the conditions recorded by schists and gneisses in the Barrovian metamorphic belt, especially along the east side of the $\mathrm{M}_{2}^{\mathrm{R}}$ metamorphic belt adjacent to the Barrovian metamorphic belt.

Thus, we conclude that in the Petersburg area, the $\mathrm{M}_{2}^{\mathrm{C}-\mathrm{R}}$ metamorphic rocks associated with the Admiralty-Revillagigedo plutonic belt and the Barrovian $\left(\mathrm{M}_{3}^{\mathrm{R}}\right)$ metamorphic belt underwent peak metamorphism at significantly different crustal depths and followed different $\mathrm{P}-\mathrm{T}$ paths. The timing of, and thermobarometric constraints on, the $\mathrm{M}_{2}^{\mathrm{C}-\mathrm{R}}, \mathrm{M}_{3}^{\mathrm{R}}$, and $\mathrm{M}_{4}^{\mathrm{C}-\mathrm{R}}$ metamorphic events indicate that the $\mathrm{M}_{3}^{\mathrm{R}}$ (Barrovian) metamorphic event mostly postdated the emplacement of plutons of the Admiralty-Revillagigedo plutonic belt and, furthermore, that $\mathrm{M}_{2}^{\mathrm{R}}$ metamorphic associations show no evidence of overprinting by $\mathrm{M}_{3}^{\mathrm{R}}$ metamorphic conditions. After metamorphism at different crustal levels, the $\mathrm{M}_{2}^{\mathrm{R}}$ and $\mathrm{M}_{3}^{\mathrm{R}}$ metamorphic belts were juxtaposed as a result of differential uplift and exhumation. In the study area, the boundary between the $M_{2}^{R}$ and $M_{3}^{R}$ metamorphic belts is near or within the Coast shear zone. Exhu- mation of the Coast Mountains is believed to have been accommodated along the Coast shear zone, which postdates emplacement of the 90-m.y.-old plutons and was probably active during Late Cretaceous time (McClelland and Mattinson, 2000). Thus, east-side-up differential movement along the Coast shear zone probably is also responsible for juxtaposition of the $M_{2}^{R}$ and $M_{3}^{R}$ metamorphic belts.

\section{References Cited}

Armstrong, J.T., 1988, Quantitative analysis of silicate and oxide minerals; comparison of Monte-Carlo, ZAF, and Phi-Rho-Z procedures, in Newbury, D.E., ed., Microbeam analysis 1988: San Francisco, Calif., San Francisco Press, p. 239-246.

Berg, H.C., Jones, D.L., and Coney, P.J., 1978, Map showing pre-Cenozoic tectonostratigraphic terranes of southeastern Alaska and adjacent areas: U.S. Geological Survey OpenFile Report 78-1085, scale 1:1,000,000, 2 sheets.

Berg, H.C., Jones, D.L, and Richter, D.H., 1972, GravinaNutzotin belt - tectonic significance of an upper Mesozoic 
sedimentary and volcanic sequence in southern and southeastern Alaska: U.S. Geological Survey Professional Paper 800-D, p. D1-D24.

Brew, D.A., 1994, Latest Mesozoic and Cenozoic magmatism in southeastern Alaska, chap. 19 of Plafker, George, and Berg, H.C. eds., The geology of Alaska, v. G-1 of the geology of North America: Boulder, Colo., Geological Society of America, p. 621-656.

Brew, D.A., 2001, The Insular-Intermontane suture zone (IISZ) of the western Coast Mountains of southeastern Alaska and British Columbia and the Adria-Europe suture zone (AESZ) of southern Europe-general description and comparison of global-scale tectonic features, in Gough, L.P., and Wilson, F.H., eds., Geologic studies in Alaska by the U.S. Geological Survey, 1999: U.S. Geological Survey Professional Paper 1633, p. 35-50.

Brew, D.A., and Ford, A.B., 1998, The Coast Mountains shear zones in southeastern Alaska-descriptions, relations, and lithologic terrane significance, in Gray, J.E., and Riehle, J.R., eds., Geologic studies in Alaska by the U.S. Geological Survey, 1996: U.S. Geological Survey Professional Paper 1595, p. 183-192.

Brew, D.A., Ford, A.B., and Himmelberg, G.R., 1989, Evolution of the western part of the Coast plutonic-metamorphic complex, south-eastern Alaska, USA; a summary, in Daly, J.S., Cliff, R.A., and Yardley, B.W.D., eds., Evolution of metamorphic belts; proceedings of the 1987 joint meeting of the Metamorphic Studies Group and IGCP project 235: Geological Society of London Special Publication 43, p. 447-452.

Brew, D.A., Ford, A.B., Himmelberg, G.R., and Drinkwater, J.L., 1995, The Coast Mountains Complex of southeastern Alaska and adjacent regions, in Koozmin, E.D., ed., Stratigraphic notes-1994: U.S. Geological Survey Bulletin 2135, p. 21-28.

Brew, D.A., Himmelberg, G.R., Loney, R.L., and Ford, A.B., 1992, Distribution and characteristics of metamorphic belts in the south-eastern Alaska part of the North American Cordillera: Journal of Metamorphic Geology, v. 10, no. 3, p. 465-482.

Brew, D.A., Ovenshine, A.T., Karl, S.M., and Hunt, S.J., 1984, Preliminary reconnaissance geologic map of the Petersburg and parts of the Port Alexander and Sumdum 1:250,000 quadrangles, southeastern Alaska: U.S. Geological Survey Open-File Report 84-171, 6 p., scale 1:250:000.

Buddington, A.F., and Chapin, Theodore, 1929, Geology and mineral deposits of southeastern Alaska: U.S. Geological Survey Bulletin 800, 398 p.

Chace, R.J., and Stowell, H.H., 1996, Late Cretaceous contact metamorphism between Wrangell and Petersburg, southeastern Alaska; a record of terrane accretion [abs.]: Geological Society of America Abstracts with Programs, v. 28 , no. 5 , p. 55.
Cohen, H.A., and Lundberg, Neil, 1993, Detrital record of the Gravina Arc, southeastern Alaska; petrology and provenance of Seymour Canal Formation sandstones: Geological Society of America Bulletin, v. 105, no. 11, p. 1400-1414.

Cook, R.D., and Crawford, M.L., 1994, Exhumation and tilting of the western metamorphic belt of the Coast Mountains orogen in southern southeastern Alaska: Tectonics, v. 13, no. 3, p. 528-537.

Cook, R.D., Crawford, M.L., Omar G.I., and Crawford, W.A., 1991, Magmatism and deformation, southern Revillagigedo Island, southeastern Alaska: Geological Society of America Bulletin, v. 103, no. 6, p. 829-841.

Crawford, M.L., Crawford, W.A., and Gehrels, G.E., 2000, Terrane assembly and structural relationships in the eastern Prince Rupert quadrangle, British Columbia, in Stowell, H.H., and McClelland, W.C., eds., Tectonics of the Coast Mountains, southeastern Alaska and British Columbia: Geological Society of America Special Paper 343, p. 1-22.

Crawford, M.L., and Hollister, L.S., 1982, Contrast of metamorphic and structural histories across the Work Channel lineament, Coast Plutonic Complex, British Columbia: Journal of Geophysical Research, v. 87, p. 3849-3860.

Crawford, M.L., Hollister, L.S., and Woodsworth, G.J., 1987, Crustal deformation and regional metamorphism across a terrane boundary, Coast Plutonic Complex, British Columbia. Tectonics, v. 6, no. 3, p. 343-361.

Douglass, S.L., and Brew, D.A., 1985, Polymetamorphism in the eastern Petersburg quadrangle, southeastern Alaska, in Bartsch-Winkler, Susan, ed., The United States Geological Survey in Alaska; accomplishments during 1984: U.S. Geological Survey Circular 967, p. 89-92.

Douglass, S.L., Webster, J.H., Burrell, P.D., Lanphere, M.L., and Brew, D.A., 1989, Major-element chemistry, radiometric ages, and locations of samples from the Petersburg and parts of the Port Alexander and Sumdum quadrangles, southeastern Alaska: U.S. Geological Survey Open-File Report 89-527, 66 p.

Ford, A.B., and Brew, D.A., 1973, Preliminary geologic and metamorphic-isograd map of he Juneau B-2 quadrangle, Alaska: U.S. Geological Survey Miscellaneous Field Studies Map MF-527, scale 1:31,680.

Ford, A.B., and Brew, D.A., 1977, Preliminary geologic and metamorphic-isograd map of northern parts of the Juneau A-1 and A-2 quadrangles, Alaska: U.S. Geological Survey Miscellaneous Field Studies Map MF-847, scale 1:31,680.

Gehrels, G.E., 2001, Geology of the Chatham Sound region, southeast Alaska and coastal British Columbia: Canadian Journal of Earth Sciences, v. 38, no. 11, p. 1479-1599.

Gehrels, G.E., McClelland, W.C., Samson, S.D., Patchett, P.J., and Brew, D.A., 1991, U-Pb geochronology of Late Cretaceous and early Tertiary plutons in the northern Coast Mountains Batholith: Canadian Journal of Earth Sciences, 
v. 28, no. 6, p. 889-911.

Gehrels, G E., McClelland, W.C., Samson, S.D., Patchett, P.J., and Jackson, J.L., 1990, Ancient continental margin assemblage in the northern Coast Mountains, Southeast Alaska and Northwest Canada: Geology, v. 18, no. 3, p. 208-211.

Gehrels, G E., McClelland, W.C., Samson, S.D., Patchett, P. J., and Orchard, M.J., 1992, Geology of the western flank of the Coast mountains between Cape Fanshaw and Taku Inlet, Southeastern Alaska: Tectonics, v. 11, no. 3, p. $567-585$.

Haeussler, P.J., 1992, Structural evolution of an arc-basin; the Gravina Belt in central Southeastern Alaska: Tectonics, v. 11 , no. 6 , p. 1245-1265.

Himmelberg, G.R., Brew, D.A., and Ford, A.B., 1991, Development of inverted metamorphic isograds in the western metamorphic belt, Juneau, Alaska: Journal of Metamorphic Geology, v. 9, no. 2, p. 165-180.

Himmelberg, G.R., Brew, D.A., and Ford, A.B., 1994a, Evaluation and application of garnet amphibolite thermobarometry, Western Metamorphic Belt near Juneau, Alaska, in Till, A.B., and Moore, T.E., eds., Geologic studies in Alaska by the U.S. Geological Survey, 1993: U.S. Geological Survey Bulletin 2107, p. 185-198.

Himmelberg, G.R., Brew, D.A., and Ford, A.B., 1994b, Petrologic characterization of pelitic schists in the western metamorphic belt, Coast plutonic-metamorphic complex, near Juneau, southeastern Alaska: U.S. Geological Survey Bulletin 2074, 18 p.

Himmelberg, G.R., Brew, D.A., and Ford, A.B., 1995, Lowgrade $\mathrm{M}_{1}$ metamorphism of the Douglas Island Volcanics, western metamorphic belt near Juneau, Alaska, in Schiffman, Peter, and Day, H.W., eds., Low-grade metamorphism of mafic rocks: Geological Society of America Special Paper 296, p. 51-65.

Himmelberg, G.R., Haeussler, P.J., and Brew, D.A., 2004, Emplacement, rapid burial, and exhumation of 90-Ma plutons in Southeastern Alaska: Canadian Journal of Earth Sciences, v. 41, no. 1, p. 87-102.

Holdaway, M.J., 1971, Stability of andalusite and the aluminum silicate phase diagram: American Journal of Science, v. 271, no. 2, p. 97-131.

Holland, T.J.B., and Powell, Roger, 1998, An internally consistent thermodynamic data set for phases of petrological interest: Journal of Metamorphic Geology, v. 16, no. 3, p. 309-343.

Ingram, G.M., and Hutton, D.H.W., 1994, The Great Tonalite Sill; emplacement into a contractional shear zone and implications for Late Cretaceous to early Eocene tectonics in southeastern Alaska and British Columbia: Geological Society of America Bulletin, v. 106, no. 5, p. 715-728.

Inman, Karen, 1992, Thermobarometric constraints on the emplacement conditions of the epidote-bearing Grand
Island Pluton, SE Alaska: Tuscaloosa, University of Alabama, M.S. thesis, $193 \mathrm{p}$.

Karl, S.M., Haeussler, P.J., and McCafferty, Anne, 1999, Reconnaissance geologic map of the Duncan CanalZarembo Island area, southeastern Alaska: U.S. Geological Survey Open-File Report 99-168, scale 1:250,000.

Klepeis, K.A., Crawford, M.L., and Gehrels, G.E., 1998, Structural history of the crustal-scale Coast shear zone north of Portland Canal, Southeast Alaska and British Columbia: Journal of Structural Geology, v. 20, no. 7, p. 883-904.

McClelland, W.C., Anovitz, L.M., and Gehrels, G.E., 1991, Thermobarometric constraints on the structural evolution of the Coast Mountains Batholith, central southeastern Alaska: Canadian Journal of Earth Sciences, v. 28, no. 6, p. 912-928.

McClelland, W.C., and Gehrels, G.E., 1990, Geology of the Duncan Canal shear zone; evidence for Early to Middle Jurassic deformation of the Alexander terrane, southeastern Alaska: Geological Society of America Bulletin, v. 102, no. 10, p. 1378-1392.

McClelland, W.C., Gehrels, G.E., Samson, S.D., and Patchett, P.J., 1992, Structural and geochronologic relations along the western flank of the Coast Mountains Batholith; Stikine River to Cape Fanshaw, central southeastern Alaska: Journal of Structural Geology, v. 100, no. 4, p. 107-123.

McClelland, W.C., and Mattinson, J.M., 2000, CretaceousTertiary evolution of the western Coast Mountains, central Southeastern Alaska, in Stowell, H.H., and McClelland, W.C., eds., Tectonics of the Coast Mountains, southeastern Alaska and British Columbia: Geological Society of America Special Paper 343, p. 159-182.

Monger, J.W.H., Price, R.A., and Tempelman-Kluit, D J., 1982, Tectonic accretion and the origin of the two major metamorphic and plutonic welts in the Canadian Cordillera: Geology, v. 10, no. 2, p. 70-75.

Pattison, D.R.M., 1992, Stability of andalusite and sillimanite and the $\mathrm{Al}_{2} \mathrm{SiO}_{5}$ triple point; constraints from the Ballachulish aureole, Scotland: Journal of Geology, v. 100, no. 4, p. 423-446.

Pattison, D.R.M., 2001, Instability of $\mathrm{Al}_{2} \mathrm{SiO}_{5}$ "triplepoint" assemblages in muscovite+biotite+quartz-bearing metapelites, with implications: American Mineralogist, v. 86, no. 11-12, p. 1414-1422.

Powell, Roger, and Holland, T.J.B., 1988, An internally consistent dataset with uncertainties and correlations; 3 . Applications to geobarometry, worked examples and a computer program: Journal of Metamorphic Geology, v. 6, no. 2, p. 173-204.

Rubin, C.M., and Saleeby, J.B., 1991, Tectonic framework of the upper Paleozoic and lower Mesozoic Alava Sequence; a revised view of the polygenetic Taku Terrane in southern Southeast Alaska: Canadian Journal of Earth 
Sciences, v. 28, no. 6, p. 881-893.

Rubin, C.M., and Saleeby, J.B., 1992, Tectonic history of the eastern edge of the Alexander Terrane, Southeast Alaska: Tectonics, v. 11, no. 3, p. 586-602.

Rubin, C.M., Saleeby, J.B., Cowan, D. S., Brandon, M.T., and McGroeder, M.F., 1990, Regionally extensive midCretaceous west-vergent thrust system in the northwestern Cordillera; implications for continent-margin tectonism: Geology, v. 18, no. 3, p. 276-280.

Spear, F.S., 1991, On the interpretation of peak metamorphic temperatures in light of garnet diffusion during cooling: Journal of Metamorphic Geology, v. 9, no. 4, p. 379-388.

Spear, F.S., 1993, Metamorphic phase equilibria and pressure-temperature-time paths: Mineralogical Society of America Monograph 1, 799 p.

Stowell, H.H., 1989, Silicate and sulphide thermobarometry of low- to medium-grade metamorphic rocks from Holkham Bay, South-east Alaska: Journal of Metamorphic Geology, v. 7, no. 3, p. 343-358.

Stowell, H.H., and Crawford, M.L., 2000, Metamorphic history of the Coast Mountains orogen, western British Columbia and southeastern Alaska, in Stowell, H.H., and McClelland, W.C., eds., Tectonics of the Coast Mountains, southeastern Alaska and British Columbia: Geological Society of America Special Paper 343, p. 257-283.

Stowell, H.H., and Goldberg, S.A., 1997, Sm-Nd garnet dating of polyphase metamorphism: northern Coast Mountains, South-eastern Alaska: Journal of Metamorphic Geology, v. 15, no. 4, p. 439-450.
Stowell, H.H., and Hooper, R.J., 1990, Structural development of the western metamorphic belt adjacent to Coast plutonic complex, southeastern Alaska; evidence from Holkham Bay: Tectonics, v. 9, no. 3, p. 391-407.

Stowell, H.H., and Inman, Karen, 1991, Comparative thermobarometry of contact metamorphic rocks; Grand Island pluton near Juneau, SE Alaska [abs.]: Geological Society of America Abstracts with Programs, v. 23, p. A445.

Stowell, H.H., and McClelland, W.C., eds., 2000, Tectonics of the Coast Mountains, southeastern Alaska and British Columbia: Geological Society of America Special Paper $343,289 \mathrm{p}$.

Stowell, H.H., and Tinkham, D.K., 2003, Integration of phase equilibria modeling and garnet Sm-Nd chronology for construction of $\mathrm{P}-\mathrm{T}-\mathrm{t}$ paths; examples from the Cordilleran Coast Plutonic Complex, USA, in Vance, Derek, Müller, Wolfgang, and Villa, I.M., eds., Geochronology; linking the isotopic record with petrology and textures: Geological Society of London Special Publication 220, p. 119-145.

Stowell, H.H., Taylor, D.L., Tinkham, D.L., Goldberg, S.A., and Ouderkirk, K.A., 2001, Contact metamorphic P-T-t paths from Sm-Nd garnet ages, phase equilibria modelling and thermobarometry; garnet ledge, south-eastern Alaska, USA: Journal of Metamorphic Geology, v. 19, no. 6, p. 645-660.

Sutter, J.F., and Crawford, M.L., 1985, Timing of metamorphism and uplift in the vicinity of Prince Rupert, British Columbia and Ketchikan, Alaska [abs.]: Geological Society of America Abstracts with Programs, v. 17, no. 6, p. 411. 